\title{
Un caso de ficción de organización partidaria o la política sin partidos: Brasil, 1889-1945*
}

Waldo Ansaldi

FCS-UNIVERSIDAD DE BUJENOS AIRES

$\Lambda$ mis queridas amigas y colegas latinoamericanistas, Maria Helena Capelato y Maria Lígia Prado, en São Paulo.

En este ensayo se hace el análisis de 56 años de historia política brasileña, que comprenden desde la proclamación de la República Velha hasta la caída del Estado Novo, caracterizados por partidos débiles, ineficaces y efímeros, lo que permite al autor detectar las prácticas determinantes para mantener el subdesarrollo partidario.

El Estado brasileño ha sido, históricilmente, cl centro de donde cmana cl clicntclismo político.

Simon Schwartzman, Bases do aulorilarismo brasileiro

\section{INTTRODUCCION}

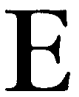
s casi un lugar común señalar que son características de la historia política de Brasil tanto la ausencia de partidos políticos orgánicos y de alcance nacional como la

* Agrade\%co las agudas obscrvacioncs y sugerencias del comentarista, mi querido amigo condición efimera de existencia que han tenido a lo largo de tal historia. La única excepción es el Partido Comunista ( $\mathrm{PCB}$, ahora desdoblado en Partido Popular Socialista, PPS, y Partido Comunista do Brasil, $\mathrm{PCB}$ ), fundado en 1922, que ha sido casi siempre una fuerza proscrita, pese a lo cual ha logrado mantener su continuidad orga-

Víctor Manucl Durand Ponte, de la Lniversidad Nacional Autónoma de Mćxico. lin toxlos los casos, la traducción de citas de los textos que en la bibliogralia figuran publicados co portugućs, es de mi responsabiliclad. 
nizativa, si bien minoritaria y sin poder convertirse en un partido de masas. Fuera de él, entonces, no existe hoy ninguna formación partidaria que haya sido creada antes del golpe militar de 1964. También es común señalar la condición de partidos creados de arriba hacia abajo-excepto el caso del PCB y el más reciente (y exitoso) del PT-, a veces inequívocamente estatalistas, y de ahí la caracterización de "partidos del Estado". EI PSD y el PTB, durante el varguismo, y la ARENA y el MDB, durante la dictadura militar, son buenos ejemplos de partidos creados por y desde el Estado, lo que no obsta para que conformen un sistema de partidos.

Atendiendo a la cuestión de la representación, Marilena Chauí, en Cultura e democracia sostiene que ha habido en Brasil tres tipos de partidos políticos: 1) clientelistas, fundados en la representación de estilo feudal y conservador y con una práctica en la que predominan el "favor" y la exclusión de los representados en las decisiones partidarias y las políticas globales; 2) populistas, que si bien tienen una concepción más progresista de la representación -entendida "como razón, voluntad general, verdad"-, no dejan de ejercer la tutela sobre sus miembros; 3) vanguardistas (o de vanguardia), caracterizados por reunir, simultáneamente, las prácticas de tutela y "favor" y por practicar un estilo pedagógico y de "encarnación de la verdad", dentro de las cuales se considera teóricamente al sujeto político como agente de transformación, si bien en la práctica se lo sustituye por la vanguardia.
La historia política brasileña de la etapa de la República puede dividirse en cuatro grandes periodos: la República Velha (1889-1930), de dominación oligárquica, con prácticas políticas minoritarias (elitistas) y restrictivas; el de la política de masas (19301964), con dos subperiodos, uno autoritario (1930-1945), cuya máxima expresión es el Estado Novo (1937. 1945), y otro democrático (1945-1964), caracterizado por el populismo; ${ }^{1}$ el de la dictadura militar (1964-1985), con su decisión de institucionalizar un nuevo Estado fundado en los principios de la doctrina de la seguridad nacional, y de crear, después de titubeos y oscilaciones, un sistema bipartidista que finalmente se tornó pluripartidista: el de construcción de la democracia política (1985-1994).

En este trabajo sólo he de ocuparme del periodo comprendido entre la proclamación de la primera República (la República Velha, en 1889) y la caída del Estado Novo, en 1945. Es decir, de un periodo semisecular en el cual la nota distintiva, en materia de hacer política, es la ausencia de verdaderos partidos políticos $\mathrm{y}$, mucho más específicamente, de un sistema de partídos de alcance nacional. Este se constituye apenas a partir de 1945, tras el

1 Francisco Weflort, para quien 19/45 -año de elección del general laurico Dutra como presiclenic- encierra el germen de la crisis de poder explicitadia bajo el gobicrno de Joño (ioulart, caracteriza al periodo 1930-1964 como autoritario, distinguiendo en él cl autoritarismo institucional de la dictadura de Vargas (1937. 1945) y cl autoritarismo paternalista o carismático de los lícleres de masas de la democracin de posgucra (19/15-1961). Populismo, 1980, p. 61. 
derrocamiento de Getúlio Vargas, y su análisis -que comprende las cuatro décadas que van de 1945 a $1985-$ es objeto de un segundo texto. ${ }^{2}$

LOS PARTIDOS DURANTE

\section{LA REPUBBLICA VELHA, 1889-1930}

En tiempos de la monarquía, dos agrupamientos políticos, conocidos con los nombres de Partido Liberal y Partido Conservador, se turnaron en el ejercicio del gobierno sin ser expresión de intereses económicos y sociales diferentes. En rigor, no se trata de verdaderos partidos políticos: no tienen estructura orgánica, plataforma, programa, disciplina o definición ideológica precisa; ni siquiera los propios parlamentarios elegidos en nombre de uno u otro actúan de modo unitario. Según compendia Richard Graham:

En los distritos se adoptaban las etiquetas de los partidos sin mucha lógica y gran parte de las luchas locales ocurrían dentro de, y no entre, los que sc llamaban partidos. Las lacciones que había cn los pueblos, entrelazadas con las familias y los vicjos lazos entre patronos y clientes, competían por la victoria electoral para obtener los cargos del poder local. Ninguna política filosó fica en particular distinguía un grupo de otro. ${ }^{3}$

Dentro de ese contexto y esa lógica, no extraña que en la práctica política predominara la búsqueda del

2 Ansaldi, "Continuidades" (en prensa).

3 Graham, "Brasil", 1991. acuerdo como respuesta al "miedo a las contiendas de partido", y el "intento de desviar las peticiones reformistas extremas", tal como se aprecia entre 1853 y 1868.

Como ha demostrado José Murilo de Carvalho, los partidos Liberal y Conservador estaban integrados primordialmente por fazendeiros, que constituyen la mitad de uno y otro partido; la otra mitad es cubierta por burócratas y profesionales, siendo los primeros de éstos mayoría en el conservadurismo y los segundos en el liberalismo. Carvalho sostiene que los partidos imperiales, al menos en sus respectivas cúpulas, "se componen de una intrincada combinación de grupos diversos en términos de ocupación y de origen social y provincial". Con todo, algunas distinciones parecen posibles: así, el Partido Conservador reúne principalmente a los grandes propietarios dedicados a la agricultura de exportación, mientras el Partido Liberal hace lo propio con quienes producen para el mercado interno. Para Emília Viotti da Costa, a su vez, las semejanzas en la composición social partidaria reducen las diferencias a mera retórica, lo cual no obsta para que dentro de cada uno de ellos se expresen, según añade, antagonismos entre un ala moderada y otra radical. Los moderados tienden "a representar los intereses de las elites agrarias tradicionales" y los radicales "a los nuevos grupos de intereses emergentes", que incluyen a sectores que se modernizan. Tras la caída del gabinete de Rio Branco (1871-1875), esa división interna contribuye "a una 
gran inestabilidad política", para salvar la cual se recurre crecientemente al emperador Pedro II (titular del poder moderador). Pero su intervención en la arena política -esto es, en el conflicto- termina produciendo un desgaste de su figura y de su función, amén de las críticas de los mismos monarquistas. ${ }^{4}$

En diciembre de 1870 se creó el primer Partido Republicano (PR), el de Río de Janeiro, integrado por apenas 30 miembros. Le siguen los PR de São Paulo (1873), Rio Grande do Sul (1882) y Minas Gerais (1887, donde asociaciones republicanas vienen actuando desde antes). En alguna medida, la creación del PR es el resultado de escisiones del liberalismo (radicales). Se trata de un partido de base social mucho más urbana que los otros dos. Según Carvalho, $55 \%$ de los cuadros republicanos son profesionales, $30 \%$ plantadores y $11 \%$ comerciantes. Emília Viotti da Costa, por su parte, señala que el núcleo del mismo, en las tres provincias citadas, lo forman estudiantes y profesionales, a los que se suman también algunos industriales, si bien en São Paulo la mayoría de los republicanos es propietaria de plantaciones; comentando las cifras de Carvalho, la autora señala que debe tenerse en cuenta que muchos plantadores son también profesionales (abogados, ingenieros, médicos), razón por la cual pueden haber sido censados tanto como unos u otros. Precisa-

${ }^{4}$ Véanse De Carvalho, "Os particlos politicos impcriatis: composição c idcologia", Consırução, 1980, cap. 8, pp. 155-176 y Da Costa, "Brasil", 1992, pp. 370-413. mente, el Partido Republicano Paulista (PRP) es el más importante del país no obstante que en 1880 cuenta sólo con 900 afiliados. Los diferentes PR son formaciones políticas integradas por hombres pertenecientes a familias tradicionales de cada una de las provincias donde el partido aparece. 5 Su fortaleza se encuentra en el sur, mientras que en el resto del país tiene un implante muy débil, excepto en Pará, provincia en la que el auge del caucho genera una posición anticentralista dentro de los núcleos política y económicamente dominantes.

Coherentes con su propuesta de organización del Estado bajo el régimen federal, los republicanos no son proclives, al menos inicialmente, a formar un partido nacional; impulsan, en cambio, una federación de partidos provinciales, cada uno de los cuales mantiene su autonomía. Tan fieles son a este principio que su pronunciamiento en favor de la abolición de la esclavitud, una materia clave del Brasil monárquico, se expresa reivindicando la prerrogativa de las provincias para decidirla, rechazando la facultad del poder central. La doble ofensiva republicana -en favor del federalismo y en contra de la monarquía-se intensifica durante el gobierno conservador de Cotegipe (18851888), durante el cual logran notable receptividad dentro del ejército, en

5 Recućrdese que durante el imperio cl país se dividió administrativamente en provincias, las cuales se convierten en estados con la repúblicat. İl cambio de denominación no es, por cicro, un dato irrelevante: cl reconocimicnto de la caliclad estatal cstá cn la basce del feclcralismo político republicano. 
cuyas filas los oficiales se muestran descontentos con la disminución de su participación en el gobierno. ${ }^{6}$

Carvalho sostiene que la consolidación del sistema político imperial resulta de la alianza entre magistrados y agricultura de exportación, que dota de unidad a la elite gobernante. Ésta comienza a debilitarse con la incorporación de nuevos elementos, los profesionales liberales, quienes desplazan a los antiguos burócratas y abren camino a una mayor representación de grupos y sectores de clase más dinámicos. Prueba de ello es la distinción entre los republicanos cariocas y los paulistas, "esto es, de un lado, el liberalismo democratizante urbano, y de otro el liberalismo predemocrático de los cafecultores paulistas". Así, los dos viejos partidos imperiales terminan por desaparecer: el Conservador, debido al debilitamiento político de los magistrados y el económico de las antiguas regiones de agricultura de exportación; el Liberal, debido a

la desbandada hacia el Partido Republicano de los líderes de las antiguas regiones marginales, ahora colocadas en la punta de la nueva agricultura de exportación y de los liberales urbanos. En cierto modo, los partidos Republicanos de São Paulo y Minas vendrán a constituir el nuevo Partido Conservador, al mismo tiempo que se tornará inviable el mantenimiento de algo semejante al vicjo Partido Liberal, excepto en las circunstancias especiales de Río Grande del Sur.

6 Da Costa, "Brasil", 1992, pp. 105-411.
Junto a la nueva expresión política creció el sector militar de la burocracia, no identificado con ninguno de los nuevos y ascendentes grupos civiles: aliada tácticamente con el PR (los nuevos conservadores), la burocracia militar contribuirá a consolidar la república, pero sus divergencias la convertirán en

un elemento de inestabilidad política durante toda la República Velha. Fi burócrata armado serí compañero menos cómodo para los dueños de la ceonomía de lo que el magistrado lo fucra en la consolidación del Scgundo Reinado. ${ }^{7}$

Durante la mayor parte de los años de la primera República, la constelación de partidos republicanos estatales es virtualmente única, monopolio que apenas fue cuestionado en Rio Grande do Sul por la presencia y la acción del Partido Federalista y, desde 1908, por el Partido Republicano Democrático, liderado por J. F. Assis Brasil.

En rigor, las formas de organización política de la república oligárquica brasileña son tributarias de (y coherentes con) la fortaleza del positivismo como ideología de la clase dominante. El positivismo, en efecto, es reacio a la idea de democracia, frente a la cual levanta la de dictadura republicana, de la cual está excluido el pueblo y hasta la propia concepción de representantes del pueblo, que, en el mejor de los casos, es restrictiva. José Murilo de Carvalho ${ }^{8}$ ha

${ }^{7}$ Carvalho, Construção, 1980, p. 176.

${ }^{8}$ Bestializados, 1087. 


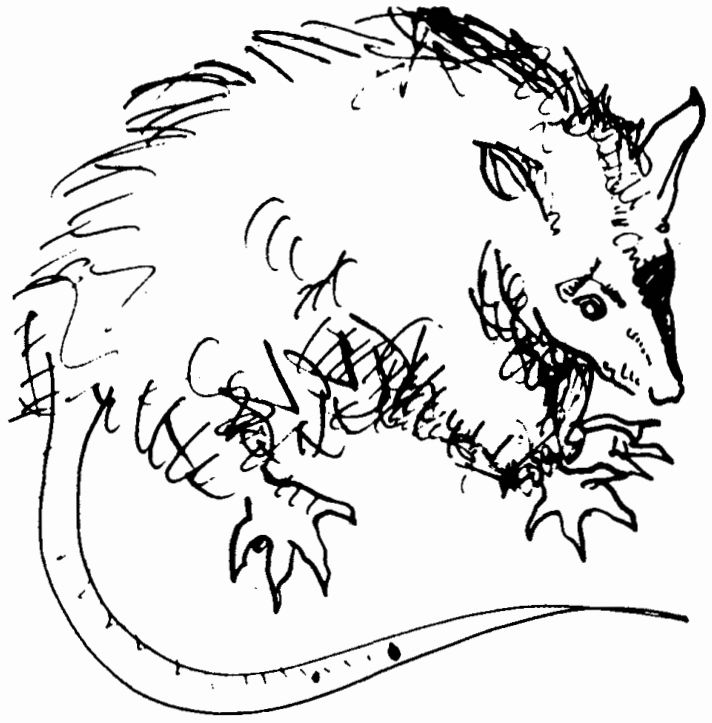

realizado un excelente análisis de la cuestión de la ciudadanía durante la dominación oligárquica, en el cual se distingue entre ciudadanos activos, poseedores de derechos civiles y de derechos políticos, y ciudadanos pasivos, sólo detentadores de derechos civiles.' La ciudadanía política se encuentra severamente restringida durante la dominación oligárquica. El sufragio no es entendido como un derecho sino como una función social y un deber, razón ésta que se invoca para sostener que el voto es concedi-

9 Esta distinción cntre títulares de ciudaclanías civil y política y titulares sólo de ciudadanía civil se encuentra también en la Argentina de la misma época, cxpresada en la fórnula albcrcliana que distingue los ciudadanos (los primeros) de los meros habitantes (los segundos). do por la sociedad a aquellos que son considerados merecedores del mismo, esto es, confiables en materia de preservación societal. ${ }^{10}$ Claro que la concesión resulta de la mera autodecisión de los dueños del poder. La legislación republicana, como antes la imperial, excluye del derecho de voto a pobres, analfabetos, mendigos, mujeres, menores de 21 años, alistados en el ejército y miembros de órdenes religiosas. ${ }^{11}$

10 Bestializados; 1987 , p. 44.

I Aluclir a exclusión de las mayorías no es apelar a la retórica; en el caso de Río de Janciro, en los comienzos de la República, signilica que el $80 \%$ de la población no tenía dercchos politicos. Véasc ibid., p. 85. 
La noción positivista de ciudadanía -escribe Carvalho- no incluía los derechos políticos así como no aceptaba los partidos y la propia democracia representativa. Admitía apenas los derechos civiles y sociales $[\ldots]$ Como vetaba la acción política, tanto revolucionaria como parlamentaria, resultaba que los derechos sociales no podrían ser conquistados por la presión de los interesados, sino que deberían ser concedidos paternalísticamente por los gobernantes. En la realidad, en esta concepción no existían siquiera los ciudadanos activos. 'Todos eran inactivos, a espera de la acción iluminada del listado, guiado por las luces del gran maestro de Montpellicr [Auguste Comte] y de sus portavoces. ${ }^{12}$

Destaco este punto porque la idea de una ciudadanía política restringida y la de un Estado paternalista constituyen un entramado sólido y de larga duración en la historia brasileña. Un corolario de esa concepción será la tentación por el "asalto del Estado", por ocupar cargos clave en el interior de éste como estrategia reformadora ("de arriba", elitista, desmovilizadora) que se despliega en el escenario estatal y no en el societal. Originó lo que el propio Carvalho ha denominado estadanía. No es casual que ésta surja con las demandas de los militares (compendiables en la idea del soldado-ciudadano) ya a finales del Imperio. Tampoco lo es que nutra el accionar de los salvacionistas en la década de 1910, de los tenentes en las de 1920 y 1930, del Estado Novo entre 1937 y 1945 y de los populistas de ahí en adelante.

12 Ibid., p. 54.
Dentro de un contexto políticoideológico dominado por el positivismo y sus ideas-fuerza en materia de organización y ejercicio del poder y la dominación, no es extraño que la acción partidaria aparezca en un plano tan elemental y restringida al remedo de partido 'como es el republicanismo. El monopolio de los PR mineiropaulistas es cuestionado en 1910 con la creación del Partido Republicano Conservador (PRC), resultado de la red de alianzas tejidas por el senador gaúcho José Gomes Pinheiro Machado (un coronel con proyección nacional) junto con congresistas representantes de los débiles estados nordestinos. El PRC es, según Boris Fausto, "un intento de creación de un partido nacional de la oligarquía". Expresa, también, la intención política de los grupos dominantes de Rio Grande do Sul de no disputar el poder federal a la alianza paulista-mineira, sino de integrarse a la misma en condiciones paritarias o en consonancia con una u otra de las partes del café com leite. Aunque en 1910 la política de éste entra en crisis y los mineiros imponen, con el apoyo de los gaúchos y del ejército, la candidatura del general Hermes da Fonseca, vencedora sobre la del paulista Rui Barbosa, la alianza mineiro-paulista se recompone en 1913 mediante el $\mathrm{Pac}$ to de Ouro Fino, permitiendo, en 1914, la elección del presidente Wenceslau Brás, de Minas Gerais. Tal reacomodamiento resulta del temor de los grupos oligárquicos de ambos estados a una ruptura de su dominio político, la cual es entrevista durante la gestión de Da Fonseca (1910-1914), especialmente por la acción de algu- 
nos oficiales del ejército (en particular coroneles) que, nucleados en el movimiento salvacionista, presionaron al presidente en favor de modificaciones en el control de los gobiernos estatales e impusieron interventores en Pernambuco, Alagoas, Bahia y Ceará, como parte de una estrategia de mayor envergadura que aspiraba a minar la dominación oligárquica en todo el país. Aunque en los estados afectados por las intervenciones era el PRC quien tenía peso considerable (si no es que lo controlan), mineiros y paulistas no están dispuestos a correr nuevos riesgos. El retorno de la alianza del café com leite, el golpe propinado por el salvacionismo y el asesinato de Pinheiro Machado, en 1915, frustran definitivamente el proyecto del PRC, cuya mayor debilidad, empero, se encuentra en el excesivo peso de las relaciones y las lealtades personales (mudables), no compensadas ni sostenidas por afinidades de intereses económicos, como sí ocurre en el caso del eje mineiro-paulista.

En términos de partidos -es decir, prescindiendo de la acción de los militares salvacionistas en la primera mitad de la década de 1910 y de los tenentes en la de 1920-, la gran fisura en el monopolio republicano, si bien restringida casi sólo a São Paulo, se produce en 1926 con la creación del Partido Democrático $(\mathrm{PD})$, mucho más profunda que la precedente del Partido Comunista do Brasil ( $\mathrm{PCB}$ ), fundado en 1922, y cuya incidencia inicial es obviamente muy débil.

El PD, cuya breve historia ha sido objeto de un excelente análisis de Ma- ria Lígia Prado, ${ }^{13}$ fue creado el 24 de febrero de 1926, día del aniversario de la promulgación de la primera Constitución republicana (1891), con la explicita intención de ser un partido político (no una mera asociación de intereses), fungir como vehículo de mediación entre la sociedad civil y el Estado y luchar por la conquista del poder. El Pl surgió a partir de tres grupos políticos distintos a los que Prado llama de la Facultad de Derecho (Waldemar Ferreira, Fancisco Morato y otros), de Marrey Júnior (disidentes del PRP) y del diario $O E s$ tado de S. Paulo Uúlio de Mesquita, un antisituacionista, opositor a la política dos governadores y sostén de la candidatura presidencial de Rui Barbosa en 1910). ${ }^{14}$ Los 601 firmantes del manifiesto-programa del 22 de marzo de 1926 aparecen mayoritariamente como hombres de clase media urbana (42.6\% son profesionales liberales y $23.4 \%$, funcionarios de escritorio, es decir 66\%), más un significativo $29 \%$ de burgueses o, si se prefiere, de miembros de las clases propietarias (fazendeiros $-15.5 \%-$, comerciantes, industriales, banqueros, exportadores), porcentaje que puede ser mayor pues muchos de los profesionales son también propietarios. No obstante esas proporciones, el PI) no es -argumenta Maria Lígia- el portavoz de las clases medias, cuyo lugar dentro del partido es subordinado; la dirección era detentada por los sectores propietarios, que en ningún mo-

13 Democracia, 1986.

1/ Sobre estc diario puede verse Maria I lelena Capelato y Maria Lígia Prado, Bratoo, 1980. 
mento ceden parcelas fundamentales de la conducción partidaria. En este sentido, Prado constata que "el origen social de la mayoría de los líderes del Partido Democrático se identificaba con el de sus opositores políticos perrepistas, o sea, provenía de las clases propietarias". ${ }^{15}$ No sólo eso: hombres de uno y otro partidos están vinculados entre sí por relaciones económicas y de parentesco. Por otra parte, no menos cierto es que el PD se constituye en "el único canal político de participación" de las clases medias urbanas, que demandan democracia política y mejoras de las deterioradas condiciones de vida. ${ }^{16}$

La existencia de dos partidos inequívocamente integrados por miembros de la burguesía paulista -hacendados, banqueros, industriales, comerciantes, exportadores- revela que las diferencias en el interior de ésta son de índole política y no expresión de intereses económicos básicos opuestos. Según Prado,

los grandes temas nacionales de la década [de 1920], como la cuestión social o la temática de la revolución, penetran el universo de esos sectores de la clase dominante y exigen una respuesta alternativa a las soluciones ya establecidas,

a los que se suman los nuevos problemas planteados por la crisis de superproducción de café. ${ }^{17}$ El PD es indudablemente, añade la historiadora brasileña, ${ }^{18}$

\footnotetext{
15 Democracia, 1986 , p. 20

16 Ibid., p. 26.

17 Ibicl., p. 21.

18 Ibid., p. 175.
}

un partido conservador, con una plataforma ideológica basada en los fundamentos liberales - la legitimidad de la propiedad, la igualdad jurídica, el individualismo y la libertad (de asociación y de expresión)-

a lo que suma un "extraordinario moralismo" (campañas contra el juego, el consumo de bebidas alcohólicas y la prostitución).

A mi juicio, el bipartidismo burgués paulista es indicador de la fractura respecto de la forma de ejercicio de la dominación política de clase, que para unos debe ser oligárquica y para otros democrática. La fracción oligárquica de la burguesía paulista se alínea en el PRP, mientras la democrática lo hace en el PD. No es el dominio de clase lo que está en cuestión, sino la forma en que éste se ejerce.

Los democráticos paulistas se inscriben en la perspectiva de quienes entienden que, "en ciertas circunstancias, conceder-dentro de límites precisos- es más eficaz que reprimir", contrastando con la postura de los republicanos. En ese sentido, a pesar de la brevedad de la experiencia,

el proyecto político-social pensado por el Partido Democrático se constituyó en la fórmula más adecuada encontrada por la clase dominante para apagar $y$ neutralizar los antagonismos sociales y las oposiciones de clase. ${ }^{19}$

Por lo demás, el PD no deja de participar de las mismas prácticas que reprocha a su adversario PR: el coronelismo, el voto de cabresto...

19 Jbid., pp. 174 y 176. 
Los democráticos paulistas no restringen su actividad a los límites estatales y buscan proyectarse a escala nacional, sin bien lo hacen con la firme convicción de subordinar a sus aliados de otros estados o regiones a la dirección de São Paulo, al que le asignaron tal función rectora en razón de su mayor desarrollo en el "progreso y la cultura" del país. Partidos Democráticos estatales fueron creados en Paraná, Santa Satarina, Río de Janeiro, Maranhão, Ceará y Pernambuco, "con pequeña repercusión y corta existencia", como acota Maria Lígia Prado. En agosto de 1927 se reunieron varios dirigentes con la intención de crear el Partido Democrático Nacional, aspiración que llevan a cabo formalmente el 21 de septiembre del mismo año, si bien su creación no alteró el estatuto de autonomía e independencia de los núcleos estatales, entre los cuales, amén del PD paulista, descuella la Aliança Libertadora do Rio Grande do Sul, constituida en enero de 1924 por las oposiciones antirrepublicanas gaúchas tras la lucha armada del año anterior, es decir el Partido Federalista (Raúl Pilla) y el Partido Republicano Democrático (Assis Brasil). En el llamado Congreso de las Oposiciones, reunido en Bagé en marzo de 1929, la Alianza se transformó en Partido Libertador y decidió integrarse en el Partido Democrático Nacional (PDN), también él sin perder su autonomía en el ámbito regional.

En 1929, después de que el presidente Washington Luís Pereira de Sousa violó el acuerdo del café com leite al proponer como su sucesor al también paulista Júlio Prestes, presidente (gobernador) del estado, mineiros y riograndenses impulsaron la Aliança Liberal (constituida el 17 de junio), cuya fórmula presidencial integran Getúlio Vargas y João Pessoa. El Partido Libertador dio su apoyo el 25 de julio, el PD paulista lo hizo el 21 de agosto (en el V Congreso Estatal, renunciando a una candidatura propia) y el PDN, sin mucho entusiasmo, en septiembre, en ocasión de su primer Congreso Nacional; en cambio, el PD del Distrito Federal se fracturó, criticando los métodos de elección de los candidatos.

En lo que podría entenderse fácilmente como un intento de conformar un auténtico partido a escala nacional, el Congreso Nacional Democrático aprobó la carta orgánica partidaria y realizó algunas leves modificaciones programáticas. Sin embargo, el intento no prosperó y el PDN desapareció al poco tiempo. Maria Lígia Prado interpreta que el fracaso se explica por las circunstancias históricas objetivas de la década de 1920:

La federación, la relativa autonomía de
las unidades estatales, la "tradición" re-
gional política brasileña, además de las
efectivas dificultades de comunicación
y transportes, teniendo en cuenta la
inmensidad del territorio nacional, fue-
ron factores concretos que dificultaron
la estructuración efectiva de un partido
nacional.

Quizá sea conveniente añadir la inexistencia de lazos sociales que permitieran construir una clase social de

20 Ibid., p. 83. 


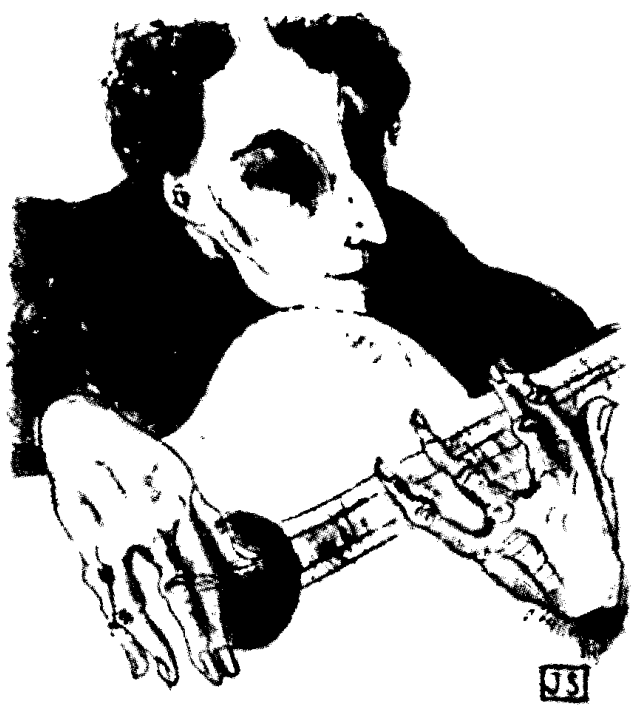

alcance nacional; en el fondo, los retazos de clases dominantes, primordialmente estatales o, en el mejor de los casos, regionales, no alcanzaron, todavía, para constituir un colectivo social capaz de superar tales estrechos límites, pensar al país como una nación y, en consecuencia, definir un proyecto nacional hegemónico.

En el debate sobre un PD nacional hay una clara expresión de un sector del partido paulista -el de Júlio de Mesquita Filho, uno de sus ideólogos- en dirección diferente a tal proyecto. La posición es expuesta por los editorialistas del diario $O$ Estado de $S$. Paulo en la edición del 29 de mayo de 1927 , la cual es así resumida por Maria Lígia Prado:
El ideal sería la formación de una ligay no de otro partido, pues las ligas constituían, según ellos, el cuadro más apropiado para las batallas políticas y sociiles, pues eran organizadas tenicndo en vista una determinada campaña y un objetivo próximo. Los partidos (de oposición), por otro lado, se fundaban para el combate de todos los días, para organización definitiva de los hombres que no se "acomodaban" en las filis gulbernamentales. De ahí, deducían los editorialistas, la necesidad de una organización partidaria regional sin la cual serían irrealizables las ligas transitoriats que se lormasen. 21

Como se aprecia, Ia idea de una formación partidaria de alcance nit-

21 Ibid., p. 81. 
cional se restringió a la de un instrumento electoral coyuntural, sólo necesario y apto para el momento de la lucha por la renovación presidencial. En cambio, reducir el partido a la escala estatal o regional fue la mejor manera de afirmar la primacía de intereses particulares y postergar la conversión de algunos de ellos en generales, lo que no fue sino otra expresión de la debilidad estructural de clases sociales regionales.

El PD no pudo colocarse bien en los conflictivos años del primer gobierno de Getúlio Vargas, el del periodo revolucionario (1930-1934), durante el cual tuvo posiciones caracterizadas por una "ambigüedad notable". A fines de 1933 desapareció, tras haberse distanciado del presidente, reconciliado con el PRP (Frente Unica, en febrero de 1932), y adoptado un programa extemporáneo (en razón de la alianza con los republicanos) que, en el plano político, reclamaba la defensa de la democracia, del federalismo, de la autonomía municipal y del voto directo (secreto y extendido a las mujeres), aunque éste sólo para elegir a los miembros de la Cámara de Diputados, manteniendo la elección indirecta (por el Congreso Nacional) para presidente de la república, y proponiendo, en el campo de la economía, el desarrollo de la producción de materias primas y su explotación industrial, la nacionalización de las minas y fuentes de calor y energía y una tendencia a la misma en el caso de las respectivas industrias. ${ }^{22}$ La derrota paulista frente a las tropas del gobier-

22 Ibid., p. 129. no federal en la insurrección de julio de 1932 es otra vuelta de tuerca en el camino de la desaparición del PD, pues sus principales dirigentes -que han acompañado a aquélla y algunos de los cuales incluso son separatistasson enviados a prisión. ${ }^{23}$

En opinión de Maria Lígia Prado, el PD dejó un legado político-ideológico que se continuó en el Partido Constitucionalista, en la efimera União Democrática Brasileira y finalmente, desde 1945, en la União Democrática Nacional (UDN).

23 Ia revuclta paulista, a veces llamada -con exageración- "revolução", es motivo de conflictivas interpretaciones. En los límites de este trabajo no es posible un tratamicnto más detenido, de modo que sólo trazo unas líncas muy gruesas. Fue posible apreciar una muestra de las disímiles interpretaciones en un excelente programa televisivo emitido por la Rede Manchete cl 9 de julio de 1993, con la participación de Vavy Pacheco Borges, Aspásia Camargo, Antõnio Candido, José Murilho de Carvalho, Boris Fausto y Paulo Sérgio Pinheiro, sobre argumento de éste y Tulio Kahn y con profusión de imágenes foto y cinematográlicas de época. Prado, Democracia, 1986, pp. 110-111, sosticne: "la cucstión política central hasta cl movimiento de 1932 consistió en la lucha entre São Paulo y cl gobierno federal. La insistencia en la lórmula de un 'interventor y paulista' como solución para el impasse creado por la intervención de João Albcrto ocupó todo el debatc político $[\ldots]$ [...ss que Paulo Nogueira Fitho] Ilama 'autonomistas radicales' eran, en verdad, separatistas. lil separatismo paulista se ha constituido en un verdadero tabú en la historiografía brasileña [...] Iintre tanto, el separatismo fue un movimiento de amplia repercusión en São Paulo, cstando profundamente entrelazado con el movimiento de 1932. Así, la socicdad paulista $\longrightarrow$ mejor, algunas fracciones de la clase dominante y sus aliados idcológicos de las clases medias- se movicron abicrtamente por cl retorno de la constitucionalidad y, clandestinamente, por cl separatismo." 
El fracaso del PD admite, seguramente, varias interpretaciones, pero no es del caso ocuparse aquí de ellas. Sólo me interesa destacar, para efectos de este trabajo, las dificultades de los sectores burgueses democráticos brasileños -e incluso de clase media urbana próximos a ellos- no sólo para alcanzar un objetivo máximo, el de desplazar del poder a los grupos burgueses oligárquicos y establecer una democracia política liberal, con todas las restricciones que se quieran, sino incluso para lograr (objetivo mínimo) constituir una fuerza política orgánica coherente y consecuente capaz de luchar en pos de la democratización o, al menos, de la liberalización. El fracaso del PD se hace todavía más patente porque el objetivo ni siquiera fue conquistado en la escala estatal. Aunque sea dicho muy rápidamente, no debe olvidarse que la ausencia de democracia política revela también la debilidad estructural de las clases subalternas (obreros, campesinos, clase media), cuya lucha no alcanza a $-y$ a veces ni siquiera se plantea- construir un espacio democrático sobre la base de la extensión de la ciudadanía política y/o del derecho a organizarse políticamente, lo que no siempre es explicable por el peso de los anarquistas, enemigos de tal lucha, y/o de los inmigrantes reacios a naturalizarse.

Durante la República Velha, la tónica general está dada por la ausencia de partidos efectivamente tales. Se presentó una ficción de organización partidaria expresada en esa formación política dominante, constituida por la constelación de Partidos Republicanos estatales, particularmente los de
São Paulo, Minas Gerais y, con menor peso, Rio Grande do Sul. Es decir, no se trata de una genuina estructura de alcance nacional, sino de una mera federación de "partidos" estatales. Tanto ellos como otras asociaciones políticas que se constituyeron en el interior de la clase dominante se caracterizan por adoptar el formato de representación de notables. ${ }^{24} \mathrm{Al}$ igual que en otros países latinoamericanos, la dominación política de clase se ejerce contemporáneamente bajo la forma oligárquica. Como he sostenido en otra parte, la oligarquía no es una clase social, sino una categoría que designa una forma de ejercicio de la dominación política de clase caracterizada por su concentración y por la angosta base social, es decir por la exclusión de la mayoría de la sociedad de los mecanismos de decisión política. La

\footnotetext{
${ }^{24}$ Sigo aquí a Göran Therborn, para quien los formatos de representación son sistemas de selección de dirigentes políticos; la "expresión quicre dar a entender que no nos reficrimos a la manera en que se consiguc la represcntación, sino más bien al contexto en el que la clasc dominante logra, mediante numerosos mecanismos diferentes, que se represente la reproducción dé sus posiciones". Dentro de los varios formatos de represcentación, cl de notables es aquel en el cual "los dirigentes políticos surgen como personalidades sobresalientes entre un público burgués, informalmente organizado, compuesto de micmbros de la clase dominante y de sus estratos aliados, abogados, y en ocasiones burócratas. Las citadas personats se van perfilando como candidatos para la función de dirigentes, de múltiples formas no institucionalizadas, en el curso de la vida diaria de la clase dominante [...] Este sistema es un excelente formato de representación de la clase dominante, mientras los dominados no se orgatnizan sólidamente para desalìarlo". Véase Therborn, Como, 1979, pp. 221, 225 y 230.
} 
dominación oligárquica puede ser ejercida por clases, fracciones o grupos sociales diversos. ${ }^{25}$ En el caso brasileño -como en el argentino entre 1880 y 1916-, la oligarquía es la forma que adopta la dominación política de la burguesía o, al menos, de sus principales sectores.

En cuanto modo o forma de dominación política de clase, el régimen oligárquico es el ejercicio de la misma por parte de un grupo minoritario que es parte de los dueños del poder económico y social. Sus características principales son:

1) Base social angosta (burgueses, terratenientes, hacendados, plantado res, mineros, comerciantes, sea cada uno de ellos por sí o bien mediante alianza de dos o más).

2) Reclutamiento cerrado de los designados para funciones de gobierno, basado en criterios de apellido o linaje, tradición, familia o parentesco (carnal, "espiritual" o compadrazgo, o resultante de alianza por unión matrimonial entre miembros de familias tradicionales), prestigio, amistad, dinero, a lo que puede añadirse, en algunos casos, formas de movilidad social ascendente tales como recompensas por habilidad política, méritos militares y/o matrimonio (diferente del antes señalado, en el cual ambos consortes pertenecen a familias tradicionales). Este sistema de selección de personal político adopta el formato de representación de notables, siendo un núcleo de reducidos integrantes.

$25 \mathrm{He}$ desarrollado este tema en Ansaldi, "Frivola", 1991.
3) Exclusión de los disidentes y/o de la oposición considerada, con razón o sin ella, como radical o peligrosa, y cooptación de individuos (transformismo molecular) o grupos potables, moderados o asimilables (transformismo orgánico).

4) Combinación de centralización y descentralización en el ejercicio del poder político mediante clientelismo, burocracia y mecanismos de control intraoligárquico.

5) Mecanismos de mediaciones y de lealtades familiares o grupales-personales, más que partidarias.

6) Autoritarismo, paternalismo, verticalismo.

7) Autopercepción positiva de la condición de ser naturalmente elegidos para ejercer el gobierno de los hombres y de la sociedad.

8) Limitación efectiva (no siempre ni necesariamente en términos legales o jurídicos) del derecho de sufragio, de elegir y de ser elegido.

9) Predominio de la dominación sobre la dirección en el plano político, no reducido a la coerción o violencia física, pues ésta va acompañada de una constante, cotidiana violencia simbólica.

10) Frecuente organización del Estado como Estado "capturado" (según la expresión de Francisco de Oliveira), lo que se traduce, entre otras consecuencias, en un Estado central más que en un Estado nacional, cuestión ésta que debe conectarse con:

11) La definición de un pacto oligárquico (o de dominación oligárquica) que expresa ciertos tipos de relaciones interregionales y entre centralización y descentralización de las 
decisiones políticas. En el caso de la República Velha brasileña, justamente, con las primeras se asiste a un delicado equilibrio mientras que con las segundas se desarrolla una situación en la cual la tendencia se presenta bajo la forma de una aparente paradoja: el poder central se refuerza gradualmente por causa y a pesar del refuerzo de los poderes locales.

La dominación oligárquica se ejerce en sociedades estructuralmente agrarias, fuertemente estratificadas, con prácticas paternalistas que funcionan en la doble dimensión de: $a$ ) transmisión de la dominación central (nacional ofederal) sobre los espacios locales y de moderación del autoritarismo estatal y $b$ ) equilibrar intereses nacionales y locales. La dóminación oligárquica es una red tendida vertical, jerárquicamente, que combina centralización y descentralización entre grupos dominantes de diferente alcance espacial (en el caso brasileño, nacional, regional, estatal, municipal o local), clientelismo y burocracia, con mecanismos de control intraoligárquico. La concentración del poder en un núcleo pequeño de personas es, en términos generales, muy alta si bien el espacio de aplicación de ese poder es reducido, proporcionalmente. De alli la necesidad de articular poder central y poderes locales. Se trata entonces de una estructura piramidal en la que cada nivel dispone de capacidad de dominio altamente concentrado y de alcance limitado, variables según la posición que se ocupe en tal pirámide, pero también según las sociedades.
La dominación oligárquica es simultáneamente concentrada y fragmentada y en ella el espacio público es privatizado. Tal privatización ocluye la posibilidad de estructurar la vida pública -la política como res publi$c a-y$ de intervención estatal para administrar democráticamente los conflictos más significativos de la sociedad, coherente con la "captura" del primero por la clase o fracción dominante. ${ }^{26}$ En fin, en ella hay clase dominante (en los términos de Gramsci) o gobernante (en los de Giddens), pero no clase dirigente.

Significativamente, la dominación oligárquica, como correspondiente con sociedades estructuralmente agrarias, encuentra sus elementos disruptivos en el espacio urbano, no en el rural. Clases medias (profesionales, estudiantes e incluso oficiales militares), trabajadores industriales y de servicios, pequeñoburgueses y burgueses (más) vinculados con actividades urbanas, son habitualmente sujetos de las luchas antioligárquicas.

Dentro de ese cuadro general de escala latinoamericana, la dominación oligárquica ęn Brasil tiene algunas especificidades. Para decirlo en los términos de Fernando Henrique Cardoso, ${ }^{27}$ el "pacto oligárquico" brasileño pergeñado por el presidente Manuel Ferraz de Campos Sales (1898-1902) consiste básicamente en:

1) Independencia entre los poderes del Estado pero con preeminencia presidencial.

26 Compendio aquí la exposición realizada cn Ansaldi, "Frivola", 1991.

27 Governos, 1985 , p. 48. 


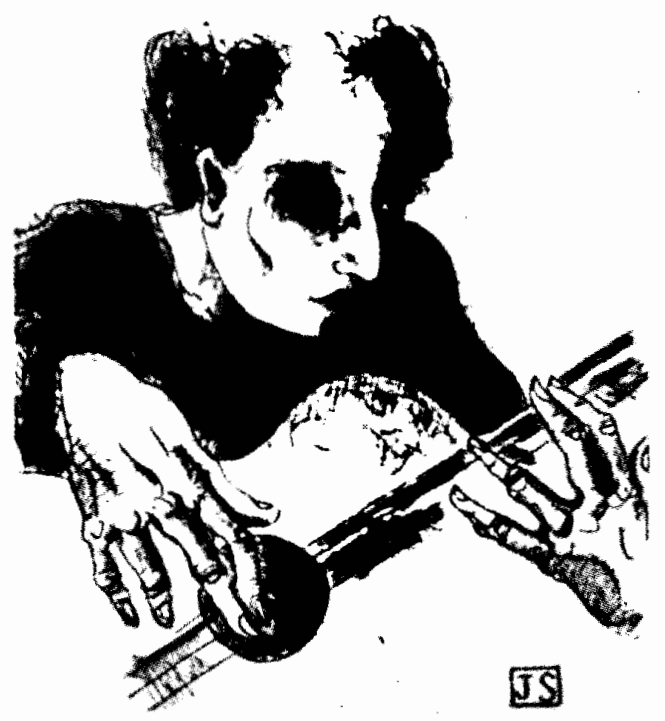

2) El poder legislativo no gobierna ni administra; el poder esclarecedor y dirigente es el ejecutivo, cuya doble función se ejerce sobre el propio Congreso.

3) Existencia de mayorías parlamentarias subordinadas a los respectivos poderes ejecutivos, en los planos federal y estatales; [los gobernadores garantizan la elección de representantes afines o dóciles al presidente de la república y nominan candidatos de su confianza para integrar las respectivas legislaturas estatales].

4) Los gobiernos estatales (las situaciones) sostienen la política del presidente, a cambio de lo cual el gobierno federal niega apoyo a las disidencias $u$ oposiciones locales. Edgar Carone resume muy bien el impacto de esta po- lítica: "Sin la simpatía federal y, naturalmente, sin apoyo local, la oposición es una actitud y no un acto". ${ }^{28}$

5) [Control de la Comisión Verificadora de Poderes]; en materia electoral, se decide que las actas válidas para definir los resultados son las firmadas por la mayoría de cada una de las Cámaras municipales, mientras la Comisión de Verificación de Poderes, la instancia parlamentaria de control de los resultados electorales, pasa a ser presidida por el presidente de la Comisión saliente (en lugar del miembro más viejo). ${ }^{29}$

28 Primeira, 1988, p. 101.

29 El control de la Comisión Parlamentaria Verificadora de los poderes es una instancia clave del sistema pergeñado por el patulista Campos Salcs, conocido con el nombre de política dos governadores. Los congresistas son 
He aludido antes a la combinación equilibrada que se construye entre poderes locales y poder central, mediante la cual éste se refuerza gradualmente a causa y a pesar del refuerzo de los primeros, acción recíproca que pone en plano relevante la figura del coronel, la institución del coronelismo y las denominadas política dos governadores y política do café com leite.

Las dos últimas son verdaderas claves de la dominación oligárquica brasileña en la escala nacional y se apoyan, a su vez, en el coronelismo o, como dice Marcel Bursztyn, en el binomio coronel/Estado. La política dos governadores consiste, para decirlo abreviadamente, en un mecanismo de gobierno sustentado en alianzas y compromisos que permiten al presidente fortalecer el poder central

expresión, obviamente, de las oligarquías estatales y su clección es el resultado de prácticas de fraude y violencia, a las que recurren tanto situacionistas como opositorcs. Hasta 1900, los resultados son registrados en actas - las cuales suclen diferir según sean firmadas por unos $u$ otros- que se envian al Congreso, donde son controladas por la citada Comisión (cinco micmbros). La presidencia de la misma es vital, por lo cual Campos Sales decide quitar un elemento de incertidumbre (nunca sé sabe quién será el parlamentario de más edad y cuál scrí su posición política) e introducir uno de certeza: la Comisión será presidida, interinamente, por quien detentaba la presidencia en la Cámara saliente, si es reclecto (en caso de no serlo, la función pasa al diputado más vicjo de la Cámara anterior). La Comisión es la encargada, entonces, de invalidar la legitimidad de los legisladores opositores, para lo cual se alega fraude o irregularidad administrativa. Esta práctica se conoce como degola (dlegücllo). De esta manera, el oficialismo se asegura que la oposición quede limitada el máximo posible. y controlar el poder legislativo, al mismo tiempo que no se inmiscuye en las situaciones estatales. En los casos de grupos oligárquicos reacios a aceptar tal política, el poder central recurre a la intervención federal en el estado en cuestión. En la práctica, la política dos governadores opera mediante el acuerdo de los grupos oligárquicos de São Paulo (productores cafetaleros) y Minas Gerais (cafetaleros y ganaderos), conocido como política do café com leite. Por ésta, como se ha visto, los núcleos dominantes paulistas y mineiros resuelven la sucesión presidencial alternando hombres de uno $y$ otro origenes, procurando aislar a los riograndenses. Empero, en los casos de divergencias entre aquéllos, los gaúchos se convierten en protagonistas principales: así, José Gomes Pinheiro Machado, Antõnio Augusto Borges de Medeiros y Getúlio Vargas, en 1910, 1919 y 1930 , respectivamente, son el tercero en discordia con la pretensión, finalmente fallida, de beneficiarse del conflicto entre los dos principales socios.

Ahora bien: ambas políticas oligárquicas -la de los gobernadores y la del café con leche- se sustentan en una sólida institución, originada en el periodo imperial y resignificada durante la república: el coronelismo, la expresión brasileña de las relaciones clientelares. Se trata de una forma de mediación y representación político-social que vincula a un jefe político local -por lo general, pero no exclusivamente, un propietario rural- y su clientela-que incluye en primer lugar a sus propios trabajadores, empleados, dependientes y parentela- y sir- 
ve de sostén oligárquico y de control social de eventuales disidencias "por abajo". La relación entre unos y otros es una variante del paternalismo, "mecanismo ideológico y social fundamental para contrabalancear el autoritarismo tanto del Estado cuanto del patriarca local" ${ }^{30} \mathrm{~A}$ medida que se extiende la ciudadanía política, la función de los coroneles se potencia en el plano electoral, es decir en el control de una masa cautiva de votantes. Pero no sería correcto limitar la definición y la eficacia del coronelismo sólo a tal dimensión -el llamado voto de cabresto-, si bien, subrayada por todos los autores que lo han estudiado, llega a ser clave. Durante la República Velha, o dominación oligárquica, más importante que el control electoral de los votantes -en definitiva, una minoría- ${ }^{31}$ es el control de la coerción.

El coronelismo es expresión del peso del poder local o municipal, una de las manifestaciones de la fragmentación del poder y la dominación, y de identificaciones y lealtades personales, de compromisos y de alianzas,

30 Bursztyn, Poder, 1984, p. 20.

31 "Entre 1898 y 1926 los númcros fde clectores] oscilan cntre 3.4 y $2.8 \%$ [dc la población], en un ciclo más descendente que cstable. La tendencia impresiona si se tiene en cuenta que la población allabetizada sc proyecta de $14.8 \%$ en 1890 a $21.5 \%$ en 1920 ." Apenas en las elecciones de 1930 votan más de un millón de electores, lo que eleva cl porcentaje a $5.7 \%$. Téngase en cuenta, para una mejor comprensión del significado de estos números, que la población brasileña es de 10 millones en 1872, de 14 en 1889 , de 20 en 1905 , de 27 en 1925 y de 34 millones en 1931. Véase Faoro, Donos, 1987 , vol. 2 , pp. 621 y 620 . combinando poder público y poder privado, poder federal y poderes locales. Es un núcleo duro en los mecanismos de ejercicio de la dominación política bajo la forma oligárquica, si bien no desaparece con ella y sí se prolonga, resignificándose, mucho más allá de $1930 .{ }^{32} \mathrm{Y}$ aunque el periodo republicano es la historia del progresivo reforzamiento del poder central, el coronel,

al mismo tiempo que el Estado se le escapa de las manos, $[\ldots]$ se apodera ya sea de la administración política de los cstados y municipios, ya sea del cont rol clectivo de las políticas y mecanismos de intervención pública al nivel de su territorio de influencia. La pérdida del control jurídico del aparato de Fistado es compensada por la sedimentación de hecho de su control político a nivel local. ${ }^{33}$

Como dice Bursztyn, se produce una situación de legitimación recíproca entre coronel y Estado.

El coronelismo estructura un mecanismo piramidal y jerárquico de ejercicio de la dominación que se despliega, según Fausto, en tres escalones o niveles: en la base de la pirámide están los coronéis, quienes controlan

32 En los límites de este trabajo, el tratamiento del coronelismo ha quedado deliberadamente restringido a las grandes líneas hasta aquí trazadas, obviando el análisis más detenido que e] tema requicre y sobre el cual es posible decir cosas difercntes de las dichas por los diversos autores que se han ocupado de él. Por mi parte, analizo cl coronclismo en una investigación de sociología histórica sobre los mecanismos de la dominación político-social oligárquica en Amé. rica latina, actualniente en curso.

33 Bursztyn, País, 1990, p. 48. 
la población de un área determinada; en un nivel intermedio se sitúan las oligarquías estatales, las "federaciones de coronéis", cuyas funciones difieren institucionalmente de las de los coroneles cuando actúan aisladamente. En el vértice de la pirámide se encuentra el gobierno federal, "producto de una alianza entre las oligarquías de los estados más importantes y, por tanto, expresión de una 'federación de oligarquías'". ${ }^{34}$ Esta estructura vertical se compadece, en la práctica, con los tres órdenes de gobierno autónomo establecidos por la primera Constitución republicana, la de 1891: el poder de la Unión, el de los estados miembros de ésta y el de los municipios, los tres con poder ejecutivo (presidente de la república, gobernador de estado y agente ejecutivo municipal, con variaciones en cada estado hasta 1930) y poder legislativo (Congreso Nacional bicameral -Senado federal y Cámara de Diputados-, Asamblea Legislativa y senados estatales -éstos hasta 1930 - y Cámara Municipal o Cámara de Concejales), fundados en elecciones directas. Según el artículo 31 de dicha Constitución, las elecciones para diputados federales se realizaban mediante sufragio directo, con garantías de representación para la minoría. Como se dijo antes, el derecho a voto se otorga a los ciudadanos -sólo varones mayores de 21 años- empadronados conforme la ley, la que excluye a analfabetos, mendigos, alistados en el ejército (desde la categoría de soldado o subteniente), los religiosos de órdenes monásti-

34 Fausto, "Brasil", 1992, p. 422. cas y de otras, sujetos a votos de obediencia, amén de las mujeres. ${ }^{35}$

Icléa Hauer da Silva sintetiza el funcionamiento electoral durante la Primera República de la siguiente manera:

La dominación oligárquica, en to que concierne al proceso electoral, era ejercida tanto en la formación de las comisiones de empadronamiento, organizadas bajo la inlluencia de los coroneles, como en la constitución de las mesas clectoralcs y de las juntas revisoras; tanto éstas como aquéllas estaban fơrmadas por autoridades municipalcs, $y$ tenían la misión de claborar las actas cuyas copias irían a constituir el diploma con que el elcgido se presentaba al Congreso para la última fase del proceso, o sea la verilicación de poderes, micntras se procedía con bastante firecuencia al "degüello" de los candidatos elcctos por la oposición, bajo el alcgato de que se hallaban encuadrados en uno de los casos de inelcgibilidad o de incompatibilidad, o simplemente por no constar la lirma de uno de los miembros de la Junta en el respectivo diploma. ${ }^{36}$

Las características del modo oligárquico de ejercer la dominación político-social contribuyen a explicar quiénes y por qué comienzan a impugnarlo. La crisis de dominación oligárquica comienza a gestarse desde la discusión por la sucesión de Epitácio Pessoa (1919-1922). En ésta, la creación de la Reação Republicana, impulsada por el poderoso Antõnio

35 Da Silva, "Representación", 1986, pp. 358-359.

36 Da Silva, Volo, Río de Janciro, 1986, p. 54; tomo la cita del artículo de José Afonso da Silva, "Represcntación", 1986, p. 360. 
Augusto Borges de Medeiros, gobernador de Rio Grande do Sul durante los años 1898-1908, 1913-1915 y 1917-1928, es un intento por unificar a grupos oligárquicos de Bahia, Pernambuco, Río de Janeiro, Rio Grande do Sul y a miembros del ejército contra los oligarcas paulistas y mineiros, levantando la candidatura de Nilo Peçanha, vicepresidente de Afonso Pena (1906-1909) y luego presidente (1909-1910), por muerte de éste. ${ }^{37} \mathrm{La}$ participación militar es una reacción a la política de Pessoa, considerada poco favorable a las fuerzas armadas, y a la difusión de las Cartas falsas, documento que ofende al ejército y cuya autoría se atribuye a Artur Bernardes, el candidato oficialista. Como señala Maria Cecília Forjaz, ${ }^{38}$ ambas rebeldías - la oligárquica y la militarse asocian para enfrentar al régimen, pero se originan en reivindicaciones y conflictos distintos. Si en los militares pesa una insatisfacción de carácter corporativo, en los grupos oligárquicos no cafetaleros la demanda es mayor participación en la dominación política. Denomino a éstos como oligarcas aperturistas.

Junto con la crisis política se desenvuelve una económica, originada en el centro del sistema capitalista, que Brasil sufre por su condición dependiente. Caen el volumen de las exportaciones y el precio de las materias primas, lo que afecta principalmente

37 Sin ser una reiteración de la estrategia de Pinheiro Machado y su PRC, en 1910, la de Borges de Madeiros tiene varios puntos en común con clla, especialmente la apclación a los debilitados estados nordestinos.

38 "Tenentismo", 1983, p. 476. a los cafetaleros (productores para la exportación), quienes socializan las pérdidas. De este modo, los burgueses no cafetaleros (que producen para el mercado interno) suman a la reivindicación política la demanda de correcciones en la economía. Una y otra no son ajenas, por añadidura, a la agitación de clases media y obrera urbanas.

Obviamente, las elecciones de 1922 se definen en favor del situacionismo. Empero, la rebeldía militar no sólo no cesa sino que se transforma en insurrección: encabezadas por tenientes, las rebeliones de julio de ese año no encuentran apoyo de los cuadros superiores ni tampoco popular y/o de las disidencias oligárquicas. El gobierno se impone rápidamente. Son éstos los primeros movimientos tenentistas, cuyos cabecillas hablan en nombre del ejército con un marcado tono defensivo-corporativo.

El fracaso tenentista de 1922 intenta ser revertido por los levantamientos de 1924, ocurridos en São Paulo, Mato Grosso, Sergipe, Amazonas, $\mathrm{Pa}$ rá y Rio Grande do Sul y concluidos en una nueva derrota. Los levantes son "un complejo de movimientos armados, insurrecciones y tentativas de golpe, flojamente articulados en términos organizacionales, si bien unificados ideológicamente y liderados por los tenientes", que ahora no hablan en nombre del ejército sino de los intereses nacionales. Si el objetivo táctico es la deposición del presidente Bernardes, el estratégico -resumido en la consigna republicanização da República-implica una efectiva transformación del régimen político: entre las varias demandas se cuentan las de 
voto secreto, limitación de las atribuciones del poder ejecutivo, establecimiento del equilibrio entre los tres poderes, centralización del Estado y corrección de los excesos de la descentralización federativa. ${ }^{39}$

Así, la segunda mitad de la década de 1920 se caracteriza por la ruptura del pacto de dominación oligárquica y la fragmentación de ésta. Forjaz añade que otros rasgos distintivos de esa situación son la diversificación del sistema político partidario y la articulación entre el tenentismo y las disidencias oligárquicas. La tónica de la lucha por la liberalización del régimen político tiene una filiación inequívoca en la concepción de la estadanía, en los cambios "por arriba", sin apelar a la movilización popular. Si se quiere, para decirlo de otra manera, en la de la revolución pasiva.

En sus análisis sobre 1930 , tanto Francisco Weffort como Boris Fausto han señalado la supremacía y la precedencia de la crisis política sobre la económica, pero, según bien señala Aspásia Camargo, ${ }^{40}$ no puede descuidarse que la industrialización y la urbanización están generando-desde la primera guerra mundial- cambios incompatibles con el pacto de dominación oligárquica. Como en otros países latinoamericanos, las burguesías que dominan oligárquicamente se revelan incapaces de satisfacer las demandas de participación en las decisiones políticas, demandas que en cierta forma son generadas por acciones realizadas

39 Ibid., p. 477. 391.

to Camargo, "A revoluçao", 1983, pp. 390- o promovidas por esas mismas burguesías.

En ese contexto, la crisis de la dominación oligárquica se asocia con la crisis de la democracia liberal, que en el caso brasileño no pasa de ser una mera declaración de principios contenida en la primera Constitución republicana, la de 1891. Siguiendo la interpretación de Francisco Weffort, puede decirse que ambas crisis son sincrónicas, aunque no necesariamente superpuestas. Una u otra o ambas crisis crea(n) condiciones que hacen posible la aparición política de las masas, cuya manifestación paradigmática es el populismo. Éste expresa, simultáneamente, la debilidad de los grupos sociales que se constituyen en dominantes por y tras la crisis oligárquica, en una coyuntura que se caracteriza por favorecer condiciones para un desarrollo autónomo relativo y el carácter peculiar que toma en las sociedades latinoamericanas -estructuralmente agrarias y dependientes- el proceso de urbanización e industrialización (Weffort).

No obstante, una precisión se impone en relación con la sincronía de ambas crisis: en América Latina -y Brasil no escapa a la generalidad-, la de la democracia liberal es, más exactamente, crisis de la idea de democracia liberal, la cual no tiene efectiva aplicación en la región, excepto casos aislados. Los años 1920 son de fuerte recusación de la democracia liberal, considerada formal, tanto desde perspectivas revolucionarias -fortalecidas por la revolución rusa y los movimientos inspirados en ella y el marxismo de la Tercera Internacional- como re- 


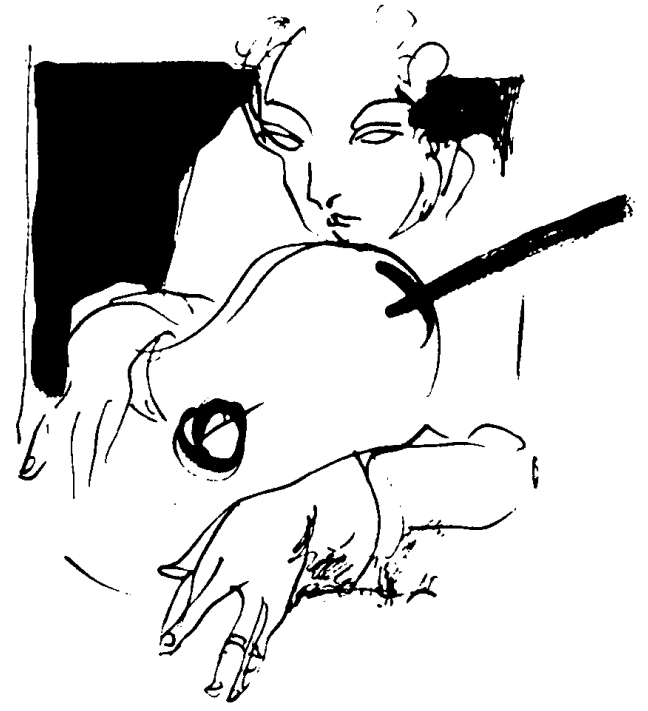

accionarias - tales como las diversas formas de corporativismo, el monarquismo morrausiano, el nazismo, etc.-, corrientes que no dejan de estar presentes en América Latina.

Por añadidura, Brasil recibe el impacto de la crisis económica del centro del sistema capitalista. La crisis de 1929-1933 afecta con mucha fuerza a la cafecultura, obligando a la quema de granos para impedir así una mayor baja de su precio. 11

Las elecciones del 1 de marzo de 1930 se realizaron en un contexto de crisis de la dominación oligárquica,

41 Entre la bibliografia sobre la crisis de 1930 en Brasil, pueden verse: Flavio Ravello Versiani, "Antes", 1988; De Paiva Abreu, "Argentina", 1988; Octavio, "Crise", 1984. ahora precipitada por la decisión del presidente Washington Luís Pereira de Sousa de impulsar, para sucederle, la candidatura del gobernador Júlio Prestes. La condición paulista de ambos implica violentar los términos de la alianza con la oligarquía de Minas Gerais. En virtud de la política del café com leite, en efecto, la sucesión debía recaer en un mineiro. La reacción de los socios contrariados fue articular un nuevo acuerdo, para lo cual apelaron, obviamente, al tercero en discordia, la oligarquía gaúcha, a la que se sumaron otros grupos regionales. La oposición al continuismo paulista se nuclea en la Aliança Liberal, que proclama la fórmula Getúlio Vargas-João Pessoa. Las elecciones consagran, una vez más, el triunfo de la fórmula situa- 
cionista. Tras ellas, algunos miembros de la derrotada Aliança Liberal comienzan a pensar en la posibilidad de una salida armada. En las conclusiones de la historia de la República Velha, Boris Fausto ${ }^{12}$ interpreta que por entonces se hace clara una diferenciación dentro de esa fuerza, más explicable en términos generacionales que ideológicos. En efecto, los jóvenes gaúchos de la llamada por Lowe "generación de 1907", tan oligarcas como sus padres, advierten que sus posibilidades de acceder al poder están limitadas a una dificil cooptación por el estrecho círculo paulista, nada favorable al riograndense. Integran ese pequeño núcleo Oswaldo Aranha, Mauricio Cardoso, Lindolfo Collor, José Antãnio Flores da Cunha, João Neves da Fontoura, Firminio Paim Filho y Getúlio Dormelles Vargas. Todos son abogados, excepto Collor; seis son hijos o parientes próximos de coroneles, cinco pertenecen a familias de estancieros y los siete tienen, hacia 1930, experiencia y una exitosa carrera política. ${ }^{43}$ Ellos son el núcleo duro de la resistencia oligárquica a la admisión del triunfo de Júlio Prestes. Buscan y obtienen el concurso de los tenientes, pese a reticencias de éstos frente a una fuerza política donde se hallan algunos de sus máximos enemigos.

$\mathrm{La}$ insurrección se prepara entre marzo y octubre de 1930. Las acciones comienzan en la madrugada del

42 Itistoria, 1985-1986, vol. III ("O I3rasil republicano"; el capítulo es: " $A$ crisc dos años veinte e a Revolução de 1930"), p. 419.

43 Lowe, "Revoluçĩo", 1983, p. 63.
3 de octubre, en Porto Alegre. El 4, Vargas da a conocer un comunicado explicando las razones del levantamiento: corregir los excesos políticos de Washington Luís y sus políticas anticrisis. "Estamos ante una contrarrevolución -dice- para readquirir la libertad, para restaurar la pureza del régimen republicano." El 24, el ejército depone al presidente e instala un triunvirato militar, el que accede transferir el gobierno a Vargas, previa garantía de éste de no purgar a la fuerza armada. El 31, Getúlio llega a Río de Janeiro, la capital del país, el 3 de noviembre asume como Jefe de Gobierno Provisorio, el 11 suspende la vigencia de la Constitución nacional y decreta la intervención de todos los estados, excepto Minas Gerais. Como acreditan los analistas, el golpe de 1930 es más que la destitución de un presidente: es el fin de un régimen político. Bien dice Faoro: 1930 significa la irrupción del elemento urbano en el mapa político nacional, tumultuosamente preparada en la década de 1920.

LOS PARTIDOS DURANTE EI. PROCISO DE CONSTTTUCIONAIIIACIÓN, 1930-1937

El nombre, la figura y la acción de Getúlio Vargas ocupan protagónicamente el escenario político brasileño a lo largo del cuarto de siglo que va de 1930 a 1954, año de su suicidio. Durante ese lapso es posible distinguir cuatro momentos diferentes: Gobierno Provisorio (1930-1934), periodo o presidencia constitucional (19341937), dictadura y Estado Novo (1937-1945), proceso democratiza- 
dor, que incluye la presidencia del general Eurico Gaspar Dutra (19451951) y el retorno de Getúlio a la presidencia (1951-1954), que corresponde a la primera de las dos décadas del populismo.

Los años treinta tienen -en gran parte de Europa y América Latina- un clima ideológico autoritario y antiliberal, que en Brasil encuentra sus fundamentos en las obras de Alberto Torres, Francisco José de Oliveira Vianna, Antõnio José Azevedo Amaral, Francisco Campos, entre los más importantes intelectuales de esa tendencia durante la dominación oligárquica. ${ }^{44}$ Después de octubre de 1930 confrontan varias propuestas autoritarias, de las cuales tres parecen ser las más relevantes: la de los tenientes, la integralista y la del Estado Novo. Ninguna de ellas brega por un sistema de partidos. La propuesta autoritaria de los tenientes tiene peso en el comienzo del proceso inaugurado por el golpe, cuando confronta con las posiciones de los oligar-

44 Puede verse al respecto la interesante propuesta de Bolívar Lamounier, "Formaçño de um pensamento político autoritário na Primcira República. Uma interpretação", en Boris Fausto, Historia, 1985-1986, vol. m, pp. 343-374. Véase también Campello de Souza, Esiado, 1976. Por lo demás, Olivcira Vianna desempeña un importante papel intelectual en la décadia de 1930 , influyendo particularmente como consultor jurídico dei Ministerio de Trabajo durante las gestiones de Lindolfo Collor (1930-1932) y Joaquim Pedro Salgado Filho (1932-1934). El primero de éstos -destacada figura de la "generación de 1907" y de la oligarquía gaúcha, abuelo materno de Fernando Collor de Mello-es clave para entender la política laboral de Vargas. Vianna Moog ha llegado a decir que Collor fue quien dio consistencia, dirección y sentido de espina dorsal a la revolución de 1930. cas aperturistas, un cuadro cuyos grandes trazos Farjaz plantea bien. El proyecto tenentista es, en lo político, autoritario, estatista, corporativista, elitista y francamente partidario de la centralización político-administrativa del Estado y enemigo de las autonomías de los estados. Los oligarcas aperturistas, en cambio, se sitúan en la posición opuesta.

En 1931 los oligarcas aperturistas y los tradicionales constituyeron Frentes Unicas en São Paulo, Minas Gerais y Rio Grande do Sul, asociaciones políticas que son expresión de la reunificación oligárquica y que superan la escisión prerrevolucionaria. Los frentes pasan de inmediato de la escala de los estados a la de la federación en pos de tres objetivos: nuevo código electoral, convocatoria a una Asamblea Constituyente y designación de un interventor civil y paulista en el gobierno de este último estado.

En tal situación, Vargas tiene sus dudas frente a las opciones. Si sus preferencias están más cerca de la posición centralizadora de los tenientes, su olfato político le permite apreciar la fuerza del movimiento oligárquico y de la demanda constitucionalista. Su respuesta resuelve la duda: decreta un nuevo código electoral (24 de febrero de 1932) y fija fecha de las elecciones para elegir a los miembros de la Asamblea Constituyente, es decir cede a la presión de los oligarcas aperturistas. El código varguista cambia algunas reglas: establece el voto directo y universal, incluyendo el femenino, dispone la aplicación de la representación proporcional (sistema ya reclamado por Rui Barbosa en 1910) e instituye 
la justicia electoral imparcial e independiente, encargada de resolver en materia de validez de las elecciones y proclamación de los candidatos. Frente a esa jugada, los tenientes no tienen capacidad de reacción y terminan no sólo debilitando su posición, sino favoreciendo la intensificación de la ofensiva oligárquica.

Dentro de ese contexto se produce el ya citado levantamiento de São Paulo, el 9 de julio de 1932, guerra civil que se prolonga casi tres meses y produce unos 700 muertos. Los esperados apoyos de grupos similares de Minas Gerais y Rio Grande do Sul no llegan o carecen de envergadura suficiente, facilitando la represión del gobierno federal. En ese sentido, Olegário Maciel, en el primero de esos estados, y Flores da Cunha, en el segundo, optan por la adhesión a Vargas. Es explicable: finalmente, mineiros y gaúchos han peleado, en 1930, contra el papel dominante de São Paulo. "Y esa dimensión todavía presente de la competición interoligárquica suplantó el temor del tenientismo" (Forjaz). Por añadidura, en uno y otro estados, los sectores que adhieren a la revuelta paulista son inequívoca expresión de la dominación oligárquica tradicional, la de los Partidos Republicanos estatales: sus dirigentes son Borges de Medeiros y Artur Bernardes, "patriarcas de la República Vieja", cuya adhesión a la conjura contribuye a rotularla como "contrarrevolución de los 'oligarcas' del antiguo régimen". 45

45 Skidmore, Brasil, 1985, pp. 37-38.
El desenlace de la guerra civil es paradójico: la derrota militar de los paulistas indica "el apogeo del poderío tenientista y simultáneamente el inicio de su declinación", pero también el triunfo político de los sublevados, pues la campaña constitucionalista no sólo continúa sino que se intensifica. Ya no es sólo "una bandera de lucha oligárquica", sino "un verdadero movimiento social". "6

En cierto sentido, la confrontación entre tenientes y oligarcas aperturistas marca una diferencia sustancial con el adjetivo que acompaña al sustantivo democracia, que debe ser social para los primeros y política para los segundos. Falta, en cambio, una posición de síntesis.

Las elecciones para constituyentes (3 de mayo de 1933) otorgan un amplio triunfo a los partidos oligárquicos y una representación minoritaria a los tenientes y algunas fuerzas aliadas (los "diputados clasistas" y algunos de los estados del norte). A fines de 1933 los tenientes pierden el control político de São Paulo y Minas Gerais. Para completar la derrota, también son desplazados en el plano militar. Los resultados de aquéllas y la propia composición de la Asamblea Constituyente marcan el claro predominio de las fuerzas estatales-federales sobre las nacionales-centralistas, lo que no es otra cosa sino el triunfo de la continuidad sobre el cambio, la persistencia de prácticas típicas de la República oligárquica. Contrario sensu, esos mismos resultados muestran la

${ }^{46}$ Spina Forjaz, "Tenentismo", 1983, p. 491. 
debilidad de las fuerzas políticas transformadoras. Sin embargo, como bien indica Angela Gomes, ${ }^{47}$ por debajo de la más visible línea de continuidad se despliegan algunas modificaciones irreversibles, entre las cuales descuella el reconocimiento de la necesidad de la intervención estatal en los planos económico, social e incluso político. Por lo demás, el triunfo de partidos estatales o regionales no significa un rechazo u oposición a Vargas, cuyo poder se refuerza al mismo tiempo que se inclina hacia su derecha y prescinde de los tenientes. Su elección por la propia Asamblea, en julio de 1934, es parte de esa definición, aun cuando ella sea con oposición. Ese poder presidencial tiene no obstante límites constitucionales, toda vez que la gestión del ejecutivo es controlada por el Consejo Nacional, y el Legislativo gana atribuciones.

Por otra parte, la Constitución de 1934 incorpora por primera vez un capítulo dedicado al "orden económico y social". Allí se establece la intervención estatal en dicho plano: nacionalización de la explotación de las riquezas del suelo y subsuelo, participación en la puesta en marcha de industrias estratégicas para la seguridad nacional y el desarrollo del país, reconocimiento de la competencia del Estado para regular el mercado de trabajo y consagrar derechos sociales. En buena medida, pues, la Carta sintetiza las líneas de "confrontación y compromiso" políticos desplegadas p. 33 . durante el primer momento del proceso iniciado con el golpe de 1930. Calificada a menudo de híbrida, ella hace lugar más a las posiciones liberal"democráticas" de los grupos tradicionales que a las reformadoras-autoritarias de los tenientes.

El momento 1934-1937 es expresión de posiciones encontradas que pretenden orientar la dirección de la sociedad brasileña. Las dudas son varias: ¿centralización o descentralización del poder?, ¿autoritarismo o democracia?, ¿protagonismo político o sujeción militar al poder civil?, ¿ampliación o restricción de las ciudadanías política y social?, ¿política de masas o política de notables?, ¿aceptación o rechazo de las reglas constitucionales?, ¿sindicatos autónomos o sujetos al Estado?...

En materia de organización de partidos se despliegan dos estrategias: una, la del tenentismo, busca crear un Partido Nacional que unifique a las corrientes "revolucionarias" y pueda enfrentar al "adversario reaccionario". Los interventores en los estados -delegados del poder ejecutivo- son la pieza clave para alcanzar el objetivo del proyecto, desplegando su actividad en su respectiva jurisdicción, paso previo a la integración de los partidos regionales en una estructura nacional. Incluso en un contexto "revolucionario", los constructores de un nuevo orden político no pueden inventar una nueva tradición y son tributarios de la definida por los oligarcas: la idea relativamente innovadora de fundar un partido de alcance nacional no consigue huir, en sus bases organizativas, "del modelo regionalista de 'ha- 


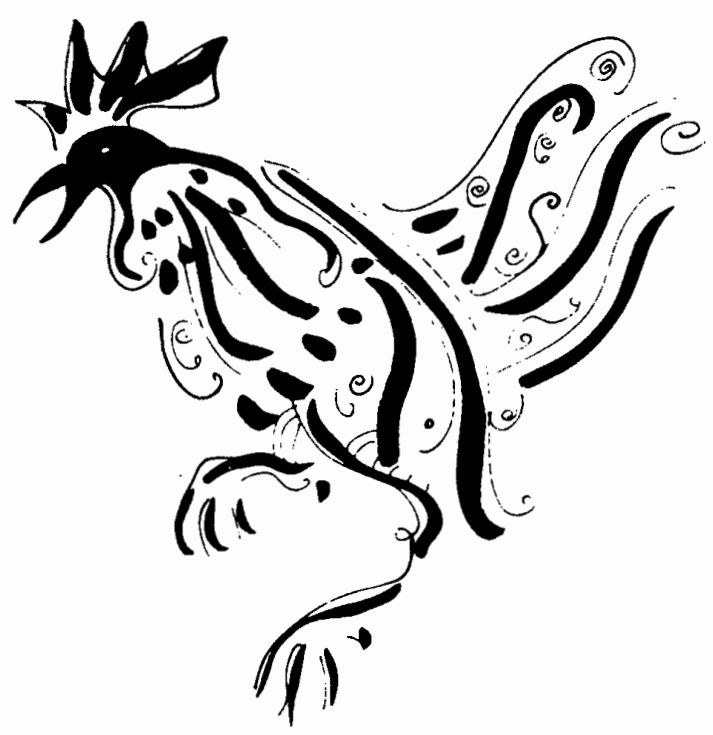

cer política'" 48 Inequívocamente, el proyecto era crear un partido político "desde arriba", desde el Estado, orientado a asegurar el continuismo de Vargas. El resultado final fue un fracaso, acreditando un éxito parcial sólo en estados del norte y noreste, donde se constituyó la União Civica Nacional (UCN), que no deja de ser expresión de los anhelos de aquéllos por afirmar, a escala nacional, sus intereses regionales, largamente postergados por la primacía de los del centro-sur.

La otra estrategia es la de las oligarquías de los estados, que rearticulan sus fuerzas apelando a dos procedimientos: la reactivación de sus viejos partidos (como el PRP y el PRM) y la

48 Ibid., pp. 30-31. creación de otros nuevos, también estatales, como el Partido Progressista (PP), en Minas Gerais, y el Partido Republicano Liberal (PRL), en Rio Grande do Sul. En esta segunda variante

los partidos, a pesar de su dimensión regionalista, presentaban un principio de formulación distinta, toda vez que disputaban exactamente con los antiguos pres, representando la fucrza y cl prestigio de los interventores lederales, directamente ligados y orientidos por el jefe del Gobierno Provisorio. Por tanto, aunque estas agrupaciones mantuviesen con las antiguas fórmulas partidarias de la República Velha una línca de continuidad, testimoniada por su carácter regional, significalan de hecho un enorme esfuctzo de renovación política de cuño nítidamente pragmático. 
Mediante estos partidos regionales de nuevo tipo, "el príncipe conseguía fortalecerse, reforzando la tendencia centralizadora del Gobierno Provisorio, a través de innumerables y valiosos aliados" y sin afectar las reservas electorales de los grupos partidarios de la autonomía de los estados. 49

Esa segunda doble estrategia reveló una vez más el peso y la continuidad de la línea de articulación entre un fuerte poder central y unos no menos fuertes poderes de los estados, en particular en los niveles ejecutivos. Así, añade Gomes,

cl montaje de la máquina partidaria regional era capaz de reflejar tanto el fortalecimiento del interventor y de parcelas de las fuerzas políticas locales como la penetración de la influencia del gobierno central en el estado y su creciente poder de interferencia. 50

La proliferación de partidos en los estados creados entre 1934 y 1937 (alrededor de 200) es también, en buena medida, muestra de la búsqueda de una organización capaz de articular las demandas de importantes sectores de la sociedad movilizados, partícipes del juego político desde el disparador golpe de octubre de 1930. Por fuera de las estrategias gubernamentales y oligárquicas, otras fuerzas intentan organizarse, procurando alcanzar una dimensión nacional. Sólo dos formaciones logran

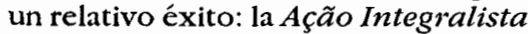
Brasileira (AIB) y la Aliança Libertadora Nacional (ALN), significativa-

49 Ibid., p. 20.

$50 \mathrm{Ibid}$. mente ubicadas en los polos opuestos del radicalismo político-social, el fascismo y el comunismo, y capaces de cooptar militantes del tenentismo en disolución. La NIB fue creada en 1932 como expresión de descontento conservador frente a la orientación del Gobierno Provisorio, mientras la AIN se fundó en marzo de 1935 con la aspiración de constituir una alternativa de izquierda fundada en la movilización de masas. Ésta es, en verdad, una de las grandes novedades de la política posgolpe, en principio privativa de la AIB, convertida en el mayor movimiento de masas del país (entre 600000 y 1000000 de adherentes).

El integrismo - tan bien estudiado por Hélgio Trindade- -51 es otra de las tres grandes corrientes autoritarias que confrontan en la década de 1930. Su ideología ecléctica, dice este politólogo, reúne un nacionalismo telúrico, el mesianismo místico del "destino histórico" de la nueva raza mestiza, el tradicionalismo social y religioso del integrismo portugués y del salazarismo, el estatismo romano, el corporativismo del fascismo italiano y el antisemitismo nazi. Nadie podría poner en duda su carácter antidemocrático... A diferencia del tenentismo, la AIB se organizó como movimiento de masas urbanas (sectores de clases media y trabajadora), que apela a ellas, las interperla, las moviliza y las organiza. El papel asignado a la movilización de masas contrasta con el autoritarismo desmovilizador de Getúlio, la tercera corriente de ese signo en los años treinta brasileños. Según

\footnotetext{
51 Integralismo, 1974.
} 
Hélgio, esa discrepancia explica por qué ni la AIB ni su jefe, Plínio Salgado, pueden ser cooptados por Vargas: el modelo desmovilizante del autoritarismo del Estado Novo es incompatible con el modelo societal movilizante, fascista, de los integristas.

La ALN es el segundo movimiento de masas urbanas. También ella nuclea a sectores de clases media y obrera. Se estructura a partir de la acción del ala legalista del Partido Comunista y del liderazgo de Luís Carlos Prestes, cuyo prestigio como jefe de la columna tenente atrae adhesiones múltiples. Skidmore considera a la ALN como un frente popular -la estrategia de los años treinta impulsada por la Tercera Internacional-con un programa que reclama la nacionalización de las empresas extranjeras y la liquidación de los latifundios. Desde otra posición, Wang Ming -representante chino en el comité ejecutivo de la Internacional Comunista-la define, en 1935, como "una organización que representa un bloque antiimperialista de clases" constituido "por iniciativa del proletariado [el PC] y las fuerzas nacionalrevolucionarias" [los tenientes]. La Alianza crece, se expande y moviliza, especialmente a partir de la escala de confrontación con la AIB. Ese crecimiento preocupa a los sectores conservadores del Congreso, que sintonizan asi con las maniobras de Vargas para obstaculizar las actividades de la ALN: en abril de 1935 se promulga una ley de seguridad nacional que da poderes especiales represivos al gobierno federal.

Vargas utiliza con inteligencia la tenaza anticomunista de la movilización y los grupos de choque integristas $y$ de la norma legal dada por el Congre. so. El ala revolucionaria del PC le brinda el componente restante: una buena razón para proscribir a la AIN. Interpretando que la vía legal se ha cerrado, aquélla organiza una insurrección que, a la postre, termina siendo mucho más una operación militar que una acción popular o, como dice Manuel Caballero, "un alzamiento militar dirigido por comunistas que eran civiles u oficiales del ejército". La insurrección se produce en noviembre de 1935, comenzando en los cuarteles de Natal y Recife, en el nordeste, pero en evidente desconexión con los de Río de Janeiro, lo que facilita la represión por las fuerzas leales al gobierno. ${ }^{52}$

Inmediatamente, Vargas obturo una ampliación de los poderes especiales. Dispuesto el estado de sitio. lia represión policial fue intensa, desarticulando a todas las formaciones de izquierda y encarcelando a miles de políticos, civiles, militares. Durante 1936 continuó la represión y el incremento de los poderes de emergencia: el estado de sitio fue prorrogado culatro veces, cada una por 90 días; un senador $y^{\prime}$ cuatro diputados federales fueron apresados y el Congreso consintió su enjuiciamiento; un nuevo Tribunal de Seguridad Nacional otorgó a Vargas un mayor poder represivo.

52 Un relato minucioso de la insurrección se encuentra en I.evine, Vargas, 1970, pp. 100124. Una síntesis de clla y una interpretación de la política de los comunistas brasilcños y del Comintern, en Manucl Caballcro, Latin America, 1986, cap. 7. Sobre la historia del Partido Comunista brasilcino pucde verse Martins Rodrigues, "O РСв", 1986 . 
En ese clima comenzaron, el mismo año, las primeras acciones para las elecciones presidenciales de enero de 1938. En 1937 se constituyó la União Democrática Brasileira (UDB), que levantó la candidatura del gobernador paulista Armando de Salles Oliveira, del denominado constitucionalismo liberal, y reclamó para el país una "robusta democracia social", con la fortaleza suficiente para resistir a la subversión de izquierda y de derecha. Un segundo candidato fue el antiguo tenentista José Américo de Almeida, de Paraíba, dirigente de la AL en 1930 , al que se considera candidato del gobierno. El escenario parece mostrar otra vez dos actores: un candidato de la oligarquía del centro-sur y otro, nordestino, del proyecto tenientista. Y las dudas: ¿una región u otra? ¿El programa de la democracia política o el de la democracia social? En junio, los integristas proclaman a Plínio Salgado; he aquí un hecho significativo, argumenta Trindade: el movimiento se transforma en partido y acepta las reglas de juego de la denostada democracia liberal. Esta tercera candidatura introduce una novedad sustancial: una fuerza nacional movilizadora quc define como enemigos al liberalismo, al socialismo, al capitalismo internacional, al judaísmo y a la masonería y que -fundándose en un cálculo de posibilidades- adopta una variante táctica que implica confrontar según reglas que desprecia.

Las dudas de Vargas respecto de su delfin alimentan la confusión, que, por lo demás, juega en favor del propio presidente, algunos de cuyos allegados $-\mathrm{y}$ posiblemente él mismo- comienzan a pensar en la posibilidad de la continuidad getulista. El ejército, a su vez, desanda sus pasos y vuelve a planear la intervención en la política de la mano del propio general Gões Monteiro. Como dice Gomes, lo que en 1934 se piensa contra Vargas, en 1937 se piensa en favor de Getúlio. Adicionalmente, en los preparativos del golpe se involucra el integrismo -a través del plan Cohen de Mourão-, que retorna así al modo de hacer política que prefiere: el asalto al poder. ${ }^{53}$

Debilidad y división de las fuerzas políticas tradicionales y de sus variantes posteriores a la década de los treinta, desarticulación y represión de la izquierda, apoyo integrista y militar, incremento del autoritarismo presidencial y retroceso de los límites legislativos... He ahí una combinación nada favorable a una respuesta democrática a las dudas de una sociedad que demanda cambios. El Plan Cohen

53 Ij Plan Cohen es preparado por cl capitán Mourão Filho -a la vez agente del scrvicio sccreto del ejército y jefe del estado mayor de la milicia integrista- en las propias olicinas del estado mayor del cjército (legal), lugar de trabaljo del capitán, lo que facilita su conocimicnto por el gencral ciócs Montciro. lil plan es adjudicado lucgo a los comunistas, procurando mostrar el peligro que éstos representan para Brasil. Así es difundido por radios y diarios, informándose que ha sido secuestrado en un operativo de las fucrass militares. Iin realidad, como explica 'rrindade, es un cjercicio interno de los integristas que muestra cómo, estratégicamentc, los comunistas húngaros toman cl poder en 1919 y cómo debe lucharse en tal situación. Salgado le dirá a Trindade, mucho más tarde, que en su momento no desmintió la falsedad del plan para no "desmoralizar a la única instilución que tenía condiciones contra el comu. nismo en Brasil, que era cl ejército". 
permitió "justificar" la ruptura de la legalidad jurídico-política. El 10 de noviembre de 1937 un golpe de Estado pone fin al segundo momento del proceso abierto en octubre de 1930 y abre el tercero, caracterizado por el intento de dar una solución a la crisis de la dominación oligárquica mediante un explícito fortalecimiento autoritario del Estado, que incluye una extensión de la ciudadanía política sin una correlativa extensión de la democracia política.

LOS PARTIDOS DURANTE EL ESTADO NOVO

El nuevo golpe mantiene a Getúlio en el ejercicio del poder, clausura el Congreso, promulga una nuevá Constitución, instaura una dictadura, derrota al integrismo y profundiza cambios estructurales de la sociedad brasileña. Noviembre de 1937 es la partida de nacimiento del Estado Novo, una solución a la crisis de dominación politica oligárquica que no expresa ni las reivindicaciones de la vieja clase dominante liberalizada, ni las demandas de transformación de los tenientes; ni es síntesis tampoco de unas y otras. El Estado Novo resuelve parcial y temporariamente esa crisis, pero no puede institucionalizar tal resolución ni afirmarla en la sociedad civil, toda vez que la dominación no se transforma en dirección o hegemonía, ni es acompañada de ésta. Conforme una línea propuesta por Francisco Weffort, puede decirse que el Estado Novo no es sólo un nuevo Estado: es también un formidable paso adelante en el proceso de construcción de un Estado moderno, nacional, proceso realizado a partir de la cúpula estatal y no de la propia sociedad.

Los años 1930-1937 son de lucha por la dominación y/o hegemonía política. Durante ella, la fracturada clase dominante no logra articular una solución concertada, consensuada, ni permite que una fracción logre subordinar a las otms (tal como la burguesía cafetalern lo hace a lo largo de la República Velha). Ninguna de las clases subalternas, a su vez, genera un "espíritu de escisión" con la fuerza y viabilidad suficientes como para constituir un sistema hegemónico alternativo. En ese contexto. no extraña que el Estado concluya al mismo tiempo que se fortalece, elevándose por encima de las clases y. finalmente, convirtiéndose en garante de las dominantes no obstante afectar los intereses inmediatos (si bien no los estratégicos) de éstas. Como dice Eli Diniz, ${ }^{54}$ "el fortalecimiento del ejecutivo [durante el Estado Novo] aparece como condición de preservación del orden y, por tanto, de sobrevivencia de los grupos dominantes", lo que no implica que el Estado tenga la condición de "capturado", característica del periodo oligárquico; por el contrario, adquiere un notable grado de autonomía, dentro de la cual el ejército juega un papel estratégico que va más allá de la propia corporación militar e influye en el crecimiento industrial (aunque no lo controle) y en el proceso de centralización política.

El Estado Novo puede interpretarse como una revolución pasiva o revo-

54 "O Estado", 1986, p. 84. 


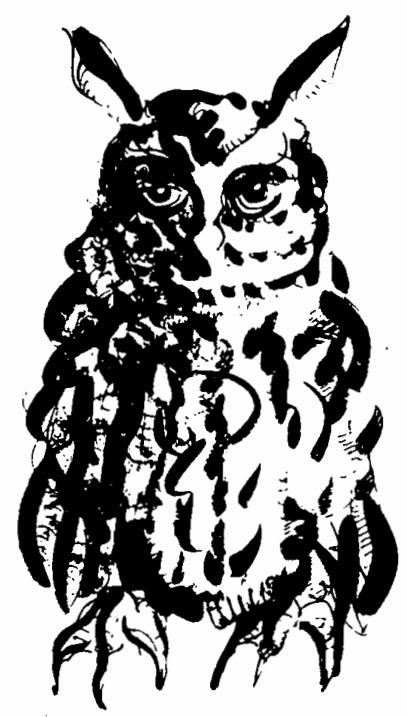

lución-restauración. ${ }^{55}$ En tal perspectiva, ese Estado cumple lo que Gramsci llama funzione piemontesa, según la cual el proceso de transformación es conducido por un Estado que sustituye y dirige a clases o grupos sociales. Esa función refuerza al Estado, en detrimento de la sociedad civil, y privilegia el uso de la dominación, incluso dictatorial, por sobre la dirección o hegemonía. 50

55 En esta interpretación coincide Carlos Nelson Coutinho, para quien la dictadura de Vargas (1937-1915) puede caractcrizarsc como "revolución pasiva" o "restauración progresista". Véase Coutinho, "Nucva", 1986.

56 ril concepto revolución pasiva es planteado por Antonio Gramsci en varios pasajes de sus Quaderni clel carcere. Ife hecho una aproximación a él en mi artículo "¿Convicne?", 1992.
Al tiempo que niega el liberalismo político, la ideología del Estado Novo proclama la corrección de los excesos del liberalismo económico. La negación es doble: de la concepción de la división de poderes -sustituida por la de su "armonía" - y de la existencia de los partidos políticos -expresión de los antagonismos y parcialidades sociales- $y$ su reemplazo por uno único, "el partido del Estado, que es también el partido de la nación", según proclama Azevedo Amaral. Es decir: como en la dominación oligárquica organicista (1889-1930), el Estado Novo (1937-1945) reduce la diversidad a la unidad, no admite la disidencia. Va más allá aún pues al identificar al Estado con la nación, dice Gomes, ${ }^{57}$

57 Gomes, "A invençĩo", 1988, pp. 221-225. 
"elimina la necesidad de cuerpos intermediarios entre pueblo y gobernante", sustituyéndolos por órganos técnicos y corporaciones que atienden "las verdaderas necesidades sociales por la observación y por la experiencia directas".

En el Estado Novo, añade la misma analista, el pueblo es concebido como "un cuerpo político jerarquizado por el trabajo [...] El trabajador brasileño era el ciudadano de la democracia social y el hombre de la nueva comunidad social". El modelo de representación estadonovista combina

la eficiencia de la organización corporativa de representación de intereses con la fierza de la representación simbólica corporizada en el presidente [concebido como pat dos pobres] [...] El contrato de fundación del Estado establecía [...] una relación personal (lo que es diferente de individual) entre el jefe de la nación, materializado en la "persona moral" del presidente Vargas, y todo el pueblo trabajador, entendido como una "persona colectiva" y no como una colección de individuos. ${ }^{58}$

Por lo demás, cuando comienza a plantearse la necesidad de reformar el Estado Novo, hacia 1944 (en consonancia con el desarrollo de la segunda guerra mundial y el alineamiento del gobierno brasileño junto al norteamericano), ${ }^{59}$ la defensa del corporativismo se funda

58 Ibid., 1988, pp. 227 y 251.

59 Recuérdese que Brasil declara la gucra a Alemania c Italia en 19亿2 y que participa cfectiva, materialmente del enfrentamiento bélico. en articulación y no en oposición a las transformaciones que el régimen tendría que sufrir [...] El corporaltivismo democrático brasileño debía ser construido por la compatibilización de un Estado fuerte con un individuo libre; de una política de protección al trabajo con una política de defensa del capital. 60

Wanderley G. dos Santos propone una hipótesis atractiva, la de la ciudadanía regulada. "Por ciudadanía regulada entiendo el concepto de ciudadanía cuyas raíces se encuentran, no en un código de valores políticos, sino en un sistema de estratificación ocupacional $[. .$.$] que [. .$.$] es definido$ por norma legal." Es decir, son ciudadanos todos quienes pertenecen a "cualquiera de las ocupaciones reconocidas y definidas por ley". En consecuencia, la ciudadanía puede extenderse mediante la reglamentación de nuevas profesiones y/u ocupaciones y la ampliación de los derechos a ellas asociados, "antes que por expansión de los valores inherentes al concepto de miembro de la comunidad".61

Vargas "establece el poder del Estado como institución, y éste comienza a ser una categoría decisiva en la sociedad brasileña". Es un Estado relativamente independiente de ésta que,

En lebrero de 1915, después de la Conlerencia de Yalta, un diplomático norteamcricano viajó a Río de Janciro para exigirle a Vargas la redcmocratización del país y cl reconocimicnto de la Unión Soviética. Las relaciones diplomáticas con ésta son establecidas el 2 de abril de cse mismo año.

60 Gomes, “ $\Lambda$ invenção” , pp. 278 y 280.

61 Santos, Cidadania, 1987, p. 68 , cursivas del autor. 
sin dejar "de ser solución de compromiso y de equilibrio" entre los grupos económicamente dominantes, "pasa a condición de árbitro que decide en nombre de los intereses nacionales". ${ }^{62}$ La mediación con la sociedad prescinde de los partidos políticos y, si bien apela a instancias corporativas, se ejerce mediante el formato de representación estatista. ${ }^{63}$

Sin embargo, el proyecto autoritario estadonovista fracasa. En 1943 se acentúan las demandas de democratización política, levantadas por una oposición dividida en al menos tres grandes corrientes: los liberales, los antiguos núcleos oligárquicos regionales y los comunistas, cuya fuerza y capacidad de movilización es notable (a pesar de la represión) y con los cuales Getúlio intenta -"olvidando" 1935 y mediante la anmnistía de sus dirigentes presos, incluyendo a Prestes, en abril de 1945, y el reconocimiento legal del $\mathrm{PC}$ - un acercamiento que le permita ampliar su margen de maniobra. En 1944, instituciones de la socie-

62 Correa Weffort, Populismo, 1980, p. 51.

63 In el formato de representación estatista "los dirigentes políticos son reclutados de entre las personas que ocupan cargos dentro del aparato del Iistado". Véase Therborn, ¿Como?, 1979 , p. 237 . Ia variante estatista en la que se inscribe el varguismo es resultado "de los reagrupamientos y cambios en el equilibrio de fuerzas entre las diversas tracciones y sectores" de la burguesía producidos por la combinación de colapso del formato tradicional de notables en la constitución de una representación unificada de la clase dominante (mucho más que en materia dc estructurar a las masas), crisis cconómica y divisiones en el interior de dicha clase. Otro tipo de formato estatista es, sicmpre scgún Therborn, la dictadura militar contrarrevolucionaria, que en Brasil es impuesta por el golpe de 1964. dad civil intensifican los reclamos por la democratización política. Reaparecen los partidos políticos como expresión de la mediación entre la sociedad civil y el Estado. Se funda la União Democrática Nacional (UIDN), considerada en sus inicios como una especie de frente integrado por los opositores a la revolución de 1930 , quienes se consideran traicionados por Vargas, y los descontentos con el autoritarismo estadonovista. El propio Vargas alienta dos formaciones políticas afines a sus posiciones, el Partido Trabalhista Brasileiro (PT'B), creado a partir de la estructura sindical corporativa, y el Partido Social Democrático (PSD), que lo es desde las estructuras regionales de poder establecidas por el régimen y que adquiere una combinación de conservadurismo y de tímido reformismo social. Aparece también un movimiento social cuya consigna es "Queremos Getúlio" -de ahí el nombre con que se lo conoce, queremismo-, con una notable capacidad de movilización urbana.

No obstante su capacidad política, su relativa apertura, las movilizaciones a su favor y las diferentes maniobras, Vargas no puede resistir la presión opositora, a la que se suman las fuerzas armadas, y el 25 de octubre de 1945 renuncia a la presidencia. Cae el Estado Novo, pero el prestigio político de Getúlio se multiplica. En 1950 volverá por la vía de las elec. ciones.

Bolivar Lamounier y Rachel Meneguello ${ }^{61}$ resumen la importancia de las

Ge Parlidos, 1986, p. 26. 
innovaciones políticas producidas por el varguismo durante su fase autoritaria en los siguientes términos:

Las instituciones decisivas del Estado brasileño fueron construidas entre 1930 y 1945 , y esto significa que surgieron al margen o que fueron implantadas, deliberadamente, contra cualquier intento de control por parte de las corrientes partidarias (cursivas mías).

A juicio de ambos, el subperiodo 1930-1937 "es eminentemente inestable" y a lo largo de él no se cristaliza "una estructura partidaria definida", mientras el subperiodo del Estado No$v o$, los ocho siguientes años,

es ostensiblemente dictatorial, un Estado burocrático sin elecciones ni partidos. La supresión de la representación vía partidos es inseparable de la implantación de una máquina estatal centralizada en esos quince años: aumenta de manera decisiva la intervención del poder público federal en la economía y en la administración de los estados; se establece la estructura sindical, que perdura hasta hoy [1986], de carícter corporativo; se desarrolla en las fucras armadas una concepción doctrinaria bien delìnida, según la cual los militares son quicnes deben amoldar políticamente a las fuerzas civiles y no a la inversa.

Hélgio Trindade, ${ }^{65}$ por su parte, destaca como "una de las consecuencias políticas del Estado Novo, en la medida en que rompe con el regionalismo político de la República Vieja", el

65 Trindade, "Partidos", 1988 , p. 6. "haber consolidado un Estado nacional hegemónico, con apoyo del ejército, que facilitó, en la fase de transición democrática de 1945, la forma. ción de partidos múltiples con una base política y legal de ámbito nacional".

El sistema de partidos es creado - 0 , mejor, comienza a crearse- en 1945. La constitución de tres partidos polí ticos en el final del Estado Novo podria ser vista, desde la óptica actual, como el comienzo de la transición a la democracia política, una interesante vía de análisis. No obstante, aquí veremos sendas fundaciones como génesis de un sistema de partidos nacional $y$ tripartito (PTB, PSD, UDN) ${ }^{66}$ Visto en perspectiva histórica, ese es su mayor efecto o impacto: consagra el fin de la política oligárquica fundada en la primacía de los partidos de los estados o regionales -que, como hemos visto, comienza a erosionarse después de 1930- y proyecta a un primer plano la dimensión nacional de las prícticas políticas, bien entendido que hay varias y fuertes líneas de continuidad en los cambios y rupturas, prácticas que son parte de la competencia entre varias formaciones actuantes en todo el pais. El periodo lo es también del pasaje del formato de representación estatista al formato partido.

(6) Hay un cuarto partido nacional, el Comunista do Brasil (PCI), pero cstá fuera del sistema de partidos en razón de su proscripción, salvo durante el breve periodo de legalidad 19/51947. Por otra parte, existen tambićn varios partidos pequeños, cuya incidencia real es, obviamentc, directamentc proporcional con su tamaño. 
El sistema de partidos de 19451965 -incluyendo tanto los tres grandes como los más pequeños (de los estados)- es nominalmente nacional, pero en lo sustancial no deja de tener fuertes componentes regionales o locales, rasgos "arcaicos" que definen a tales formaciones como partidos de mandonismo, con apelaciones al patronazgo y al clientelismo, o bien, en los más "modernos", al liderazgo carismático que vincula a un líder (de diferente magnitud, desde la escala meramente local a la nacional) con sus bases o "el pueblo" (o povo), cuando no una combinación de unos y otro. Un elemento central del funcionamiento del sistema - que se redefine en esos años y se continúa durante la dictadura y la transición a la democracia política- es la politica de alianzas para el control del poder, cuando no apenas del gobierno, en los niveles local, estatal y federal, alianzas que no excluyen la posibilidad de ser concertadas incluso entre fuerzas antitéticas o antagónicas. Así, compromisos y alianzas continúan definiendo el modo brasileño de hacer política por parte de los grupos que disputan el ejercicio de la dominación y/o la dirección de la sociedad.

\section{Biblogorafí}

- Ansaldi, Waldo (1991): "Continuidades y rupturas en un sistema de partidos políticos en situación de dictadura: Brasil, 18641985", en Silvia Dutrénit (comp.), La diversidad de lo partidarto durante la dictadura: Argentina, Brasil, Uruguay, Instituto Mora, México (en prensa). invocar al genio de la lámpara? Fil uso de
, las categorías gramscianas en el análisis de la historia de las sociedades latinoamericanas", Istudios Sociales. Revista Universitaria Semestral, núm. 2, Santa Fic, enero-junio 1992, pp. 15-65. Mismo artículo, en Carlos Kohn, Hugo Cabcllo, liduardo Zuleta y otros (comps.), Gramsci. Memoria y vigencia de una pasión polílica, Consejo de Publicaciones de la Universidad de Los Andes y Fiscucla de Filosolía de la Universidad Central de Venczucla, Mérida, 1992, pp. 275-308.

-, "Frívola y casquivana, mano de hicrro en guante de seda. Una propuesta para conceptualizar el término oligarquía en América Latina", Socialismo y Participación, núm. 56, Lima, dicicmbre 1991, pp. 15-20. (Tambićn en: Cuadernos del Claeh, año 17, núm. 61, julio 1992, Montevicico, pp. 43-18, y en Patricia liunes (comp.), América Latina: planteos, problemas, preguntcas, Manucl Suárez Editor, Buenos Aircs, 1992, pp. 13-20.)

-Bursztyn, Marcel, O país das alianças. Blites e continuísmo no Brasil, Vozes, Petrópolis, 1990.

- O poder dos donos. Planejamento e clientelismo no Nordeste, Vores, Petrópolis, 1990.

-Caballero, Manucl, Latin America and the Comintern, Londres, Cambridge University Press, 1986. (Edición en español: La Internacional Comunista y la revolución latinoamericana 1919-1934, Nueva Socicdad, Caracas, 1987.)

-Camargo, $\Lambda$ spásia, "A Revolução das elites: clivagens regionatis e centralização política", en Universidad Federal de Río Grande do Sul. Pró-Rcitoria de Extensão, Simpósio sobre a Revolução de 30, Eirus, Porto Alegre, 1983, pp. 383-118. [ill simposio tuvo lugar en octubre de 1980.I

-Capelato, Maria Ifelena y Maria lígia Prado, O bravo malutino (Imprensa $e$ 
ideología no jormal "O Estado de S. Paulo"), Editora Alfa Omega, São Paulo, 1980.

- Cardoso, Fernando Henrique, "Dos governos militares a Prudente-Campos Sales", en Boris Fausto (comp.), IIistória geral da civilização brasileira, vol. III, "O Brasil republicano", tomo I, Difel, São Paulo, 1985, pp. 13-50.

- Carone, Edgar, A Primeira República (1889-1930). Texto e contexto, Editora Bertrand Brasil, Río de Janeiro, 4a. edición, 1988.

- Carvalho, José Murilo de, Obestializados. O Rio de Janeiro a República que não foi, Companhia das Letras, São Paulo, 1987.

A constmuçao da orden. A elile polílica imperial, Editora Campus, Río de Janeiro, 1980.

-Coutinho, Carlos Nelson, "Nueva lectura del populismo brasileño", La Ciudad Futura, núm. 6, agosto 1986, Buenos Aires, suplemento/4, "Gramsci en $\Lambda$ mérica Latina".

-Chauí, Marilena, Cultura e democracia, Moderna, São Paulo, 3a. edición, 1984.

-Costa, Emília Viotti da, "Brasil: la era de la reforma, 1870-1899", en Lcslic Bethell (comp.), Historia de América Latina, "Amćrica del Sur, c. 1870-1930", Editorial Crítica, Barcelona, vol. 10, cap. 14, pp. 370-413.

-Diniz, Eli, "O Estado Novo: estrutura de poder. Relações de classes", en Boris Fausto (comp.), História geral da civilização brasileira, vol. III, "O Brasil republicano", tomo III, Difel, São Paulo, 3a. edición, pp. 77-120.

-Faoro, Raymundo, Os donos do poder: Formação do patronalo político brasileiro, Editora Globo, Río de Janeiro, 2 vols., 7a. edición, 1987.

-Fausto, Boris, "Brasil: estructura social y política de la Primera República, 1889-1930", en Leslic Bethell, Historia de América Latina, vol. 10, "América del
Sur, c. 1870-1930", Editorial Crítica, Barcelona, 1992.

- (comp.), Itstória geral da civilização brasileira, 1 vols., "O Brasil republicano", vol. III, Difcl, São Paulo, 1985-86.

-Forjaz, Maria Cecília Spina, "Tenentismo e revolução de 30", en Universidade Federal de Rio Grande do Sul. Pré-Reitoria de Extensão, Simpósio sobre a Revolução de 30, Erus, Porto Alegre, 1983, pp. 475-503.

-Gomes, Angela de Castro, "Confronto e compromiso no proceso de constitucionalização (1930-1935)", en Boris Fausto (comp.), História geral da civilização brasileira, 3 vols., "O Brasil republicano", vol. III, Difcl, São Paulo, 3a. cdición, pp. 7-75. - A invenção do trabalhismo, Vértice, Editora Revista dos Tribunales/Instituto Universitário de Pesquisas do Rio de Janciro, São Paulo y Río de Janciro, 1988.

-Graham, Richard, "Brasil (18501870)", en Leslic Bethell, Hisloria de América Latina, vol. 6, "América Latina independiente, 1820-1870", Editorial Crítica, Barcelona, 1991, cap. 10, pp. 378118.

-Ianni, Octavio, "A crise do calé a Revoluçâo dc 30", en O. Janni, Origens agrárias do Rslado brasileiro, Editora Brasiliense, São Paulo, 1981, pp. 192-205.

-Lamounier, Bolivar e Rachel Mencgucllo, Partidos políticos e consolidação democrálica: o caso brasileiro, liditora Brasilicnse, São Paulo, 1986.

-Levine, Robert M., The Vargas Regime: The critical years 1934-1938, Columbia University Press, Nueva York y Londres, 1970.

-lowe, Joseph, " $\Lambda$ Revolução de $30 \mathrm{e}$ o regionalismo gaúcho", en Universidade Federal de Rio Grande do Sul. Pró-Reitoria de Extensâo, Simpósio sobre a Revolução de 30, Erus, Porto Alegrc, 1983 , pp. 60-83.

- Paiva Abreu, Marcelo de, "La Argentina y Brasil en los años treinta. Efectos de 
la política económica internacional británica y estadunidense", en Rosemary Thorp (comp.), América Latina en los años treinta. El papel de la periferia en la crisis mundial, Fondo de Cultura Económica, México, 1988, pp. 171-190.

-Prado, Maria Lígia Coelho, A democracia ilustrada. O Partido Democrático de São Paulo, 1926-1934, Editora Arica, São Paulo, 1986.

-Ravello Versiani, Flavio, "Antes de la depresión: la industria brasileña en los años veinte", en Rosemary Thorp (comp.), América Latina en los años treinta. El papel de la periferia en la crisis mundial, rondo de Cultura Económica, México, 1988, pp. 191-216.

-Rodrigues, L.eõncio Martins, "PCB: OS dirigentes c a organização", cn Boris Fausto (comp.), IIistória geral da civilização brasileira, 3 vols., "O Brasil republicano", Difel, São Paulo, 3a. edición, vol. III, pp. 361-443.

-Santos, Wanderley Guilherme dos, $\mathrm{CA}$ dadania e justiça. A política social na ordem brasiletra, Río de Janciro, 2a. edición revisada y actualizada, 1987.

-Silva, José Afonso da, "Representación proporcional; electos corporativos en Brasil", en Varios, Sistemas electorales y represenlación política en Latinoamérica, Fundación Friedrich
Ebert/Instituto de Cooperación Iberoamericana, Madrid, vol. II, pp. 353-393.

-Skidmore, Thomas, Brasil: de Getúlio Vargas a Castelo Branco (1930-1964), Paz e Terra, Río de Janeiro, 8a. edición, 1985. (Primera edición en inglés, 1967.)

-Souza, Maria do Carmo Campello de, Estado e partidos políticos no Brasil (1930-1961), Editora Alfa-Omega, São Paulo, 1976.

-Therborn, Göran, ¿Cómo domina la clase dominante?, Siglo XXI de lispaña Editores, Madricl, 1979.

-Trindade, I lélgio, Inlegralismo: o fascismo brasileiro na década de 30, Difel, Sĩo Paulo, 1974.

- "Partidos políticos y transición democrática en el Brisil", Jdeas en Ciencias Sociales, año แI, núm. 7, Bucnos Aircs, pp. 3-20. Reproducido, en otra traducción, como "Partidos políticos y transición democrática: el populismo y el antipopulismo en la politica de Brasil", en Lorenzo Meyer y José Luis Reyna (comps.), Los sistemas políticos en dmérica Latina, Siglo XXI Editores/Universidad de las Naciones Unidas, México, 1989, pp. 23-40.

- Welfort, Francisco Correa, O populismo na política brasileira, Paz e Terra, Río de Janeiro, 1980. 